\title{
Cultural Heterogeneity and Law: Pornography, Blasphemy, and the First Amendment
}

\author{
Robert C. Post $\dagger$
}

Feminists have recently sought the regulation of pornography on the grounds that pornography injures women as a group. This feminist challenge raises $a$ vital constitutional question about the kinds of values the first amendment should protect. Professor Post here considers that question in light of three alternative means by which a legal order might be structured for a society made up of heterogenous groups: (1) assimilationism, which seeks social uniformity by imposing on all individuals the values of a dominant cultural group; (2) pluralism, which nurtures social diversity by protecting the values of competing cultural groups; and (3) individualism, which favors the choices of individuals over the values of any cultural group. He identifies the differences and connections among these perspectives by comparing the English and American laws against blasphemy. That comparison reveals the profoundly individualist character of American first amendment doctrine. Professor Post argues that the feminist challenge against pornography is controversial because it represents a pluralist challenge to our first amendment individualism, and he concludes that the success of the feminist challenge depends on its proponents' ability to offer a convincing vision of the first amendment that is consistent with pluralist values.

Twenty-five years ago legal academics viewed the law of obscenity as the regulation of sex. Laws prohibiting obscenity were understood to stem from "traditional notions, rooted in this country's religious antecedents, of governmental responsibility for communal and individual 'decency' and 'morality.' "1 They protected our common cultural "environment." 2 The constitutional issue posed by such laws, therefore, was whether the first amendment permitted expression to be suppressed for the purpose of preserving "the purity of the community and ... the

$\dagger$ Professor of Law, Boalt Hall School of Law, University of California, Berkeley. A.B. 1969, Harvard College; J.D. 1977, Yale Law School; Ph.D. 1980, Harvard University. This essay is based upon a paper originally delivered at a conference on the first amendment sponsored by the Faculty of Laws at the University of Tel Aviv. It has since been much improved by the comments of many good friends, for which I am very grateful.

1. Henkin, Morals and the Constitution: The Sin of Obscenity, 63 CoLUM. L. REv. 391, 391 (1963).

2. A. Bickel, The Morality of Consent 74 (1975); see Paris Adult Theatre I v. Slaton, 413 U.S. 49, 58-61 (1973). 
salvation and welfare of the "consumer." "3

During the 1980's, however, this view of obscenity changed, in large measure because of the remarkable work of Catharine MacKinnon ${ }^{4}$ and Andrea Dworkin. ${ }^{5}$ For MacKinnon and Dworkin the issue is neither decency nor community morality, but rather the oppression of women. They use the term "pornography" to signify their concern with the sexually explicit subordination of women, and not with mere prurience. ${ }^{6}$ Pornography is for them "an institution of gender inequality," which not only causes discrete acts of sexual violence against individual women, but, more fundamentally, which hurts "individuals, not as individuals in a one-at-a-time sense, but as niembers of the group "women." "7 Women as a group are harmed because "pornography constructs the social reality of gender," and hence in a deep sense all women are "defined in pornographic terms" as sexually unequal. ${ }^{8}$ The efforts of MacKinnon and Dworkin have posed an inportant constitutional question for the 1980's, which is whether the first amendnent will permit expression to be suppressed for the purpose of preventing this assault on the "status" of women as a group. ${ }^{10}$

3. Henkin, supra note 1, at 395.

4. See C. MAcKinnon, Feminism Unmodified: Discourses on Life and LaW (1987).

5. See A. DWorkin, Pornography: Men Possessing Women (1981).

6. Dworkin, Against the Male Flood: Censorship, Pornography, and Equality, 8 HARv. WOMEN'S L.J. 1, 15-17 (1985).

7. C. MACKINNON, supra note 4, at 148,156 (emphasis in original).

8. Id. at 166; see also id. at 161: "[P]ornography constructs women and sex, defines what 'woman' means and what sexuality is, in terms of each other" (emphasis in original). The emphasis on the social construction of gender helps to explain why MacKinnon and Dworkin include in their definition of pornography " "the use of men, children or transsexuals in the place of women." " Id. at 146 n.1. Because MacKinnon and Dworkin are chiefly concerned with the nature of the female social role, they are relatively indifferent as to the question of whether that role is filled by men or transsexuals. Of course to the extent that the female role comes characteristically to be filled by persons other than women, the claim that the role is in fact that of the female gender becomes problematic.

9. Id. at 178.

10. See, e.g., Ameriean Booksellers Ass'n v. Hudnut, 771 F.2d 323, 328-32 (7th Cir. 1985), summarily aff'd, 106 S. Ct. 1172 (1986); Branit, Reconciling Free Speech and Equality: What Justifies Censorship?, 9 Harv. J.L. \& PuB. Pol'y 429 (1986); Brest \& Vandenberg, Politics, Feminism, and the Constitution: The Anti-Pornography Movement in Minneapolis, 39 STAN. L. REV. 607, 659-60 (1987); Bryden, Between Two Constitutions: Feminism and Pornography, 2 Const. Commentary 147, 152-53 (1985); Chemerinsky \& McGeady, Outlawing Pornography: What We Gain, What We Lose, 12 Hum. RTs. 24 (No. 3, Spring 1985); Emerson, Pornography and the First Amendment: A Reply to Professor MacKinnon, 3 Y ALE L. \& PoL'y Rev. 130 (1984); Jacobs, Patterns of Violence: A Feminist Perspective on the Regulation of Pornography, 7 HARV. WoMen's L.J. 5, $41-45$ (1984); Lynn, 'Civil Rights' Ordinances and the Attorney General's Commission: New Developments in Pornography Regulation, 21 HARv. C.R.-C.L. L. Rev. 27 (1986); Stone, AntiPornography Legislation as Viewpoint-Discrimination, 9 HARV. J.L. \& PUB. PoL'Y 461 (1986); Sunstein, Pornography and the First Amendment, 1986 DUKE L.J. 589, 591-92.

For a summary of recent developments in England, which have followed a similar course, see A. Simpson, Pornography \& Polmics: A look Back to the Williams Committee 72 (1983): 
This Article is meant to propose a tentative framework to assist in the analysis of that question. It is a question that implicates many of the same issues as those raised by government attempts to regulate speech that vilifies particular minorities or ethnic cultures. ${ }^{11}$ At the most general level, it is a question that involves the obligations of a legal order in a lieterogeneous society coinprised of diverse and competitive groups. In this Article I sliall suggest three different ways of understanding these obligations. I shall then explore the historical and sociological underpinnings of these perspectives by examining the crime of blasphemy in England and America. Finally, I shall bring these perspectives to bear on the constitutional cliallenge posed by the contemporary feminist critique of pornograpliy.

We can begin by noting the outlines of a rather crude triptycli. Consider the options available to a legal order in a society consisting of heterogeneous groups. The law can place the autliority of legal sanctions behind the cultural perspectives of a dominant group; or it can foster a regime in whicl diverse groups can escape from sucli domination and maintain their distinctive values; or it can ignore group values and perspectives altogether and recognize only the claims of individuals. I shall call these three options, respectively, assimilationisin, pluralism, and individualism. ${ }^{12}$ Most legal orders, and certainly our own, contain elements of eacli of these three options, and are, for example, individualist with respect to one issue, but assimilationist witl respect to anotlier.

Assimilationist law places the force of the state belind the cultural perspective of a particular, dominant group. If a society is relatively hoinogeneous, so that the values of this group are representative of the society as a whole, assimilationist law can be said to be expressive of common cominunity norins. But if the society is heterogeneous, assimi-

At a theoretical level however it is clear that whereas the Williams Committee saw pornography primarily as a public nuisance problem, the harm flowing from it consisting in the offence it caused, many feminists do not accept this. Pornography is seen as a political problem in that it is a mechanism for securing a certain distribution of power in society, one in which women lose out and is in itself an act of violence; the slogan "pornography is violence against women" rejects the notion that the harm produced by pornography is to be sought in the consequences of pornography, but not in the material itself.

11. For two recent discussions of these issues, see D. Downs, Nazis IN Skokie: Freedom, COMmunity, AND THE First AMENDMENT (1985); Delgado, Words that Wound: A Tort Action for Racial Insults, Epithets, and Name-Calling, 17 HARV. C.R.-C.L. L. REv. 133 (1982).

12. These three options do not, of course, exhaust the field. For example, a legal order may found its laws upon neither group values nor individual claims, but upon instrumental reason. On the relationship between instrumental reason and constitutional rights, see Post, Between Governance and Management: The History and Theory of the Public Forum, 34 UCLA L. REv. 1713 (1987). The question of pornography, however, does not raise technological issues of this kind. 
lationist law can instead be understood as an attempt, which may be niore or less hegemonic in character, to extend the values of a dominant group to the larger society. ${ }^{13}$ An example of an assimilationist law is the federal anti-bigamy statute, which was upheld in Reynolds v. United States ${ }^{14}$ on the grounds, inter alia, that "[p]olygainy has always been odious ainong the northern and western nations of Europe."15 Another exaniple is the requirement that school children salute the flag, which was upheld in Minersville School District v. Gobitis ${ }^{16}$ on the grounds that a state can enforce "the traditions of a people" and hence "create that continuity of a treasured cominon life which constitutes a civilization."17

In each of these examples law was used to support the values of a domimant culture, notwithstanding the dissenting values of marginal or subordinate groups. Front the perspective of these latter groups, assimilationist law can often appear based in "cultural chauvinism, social hypocrisy, and disdain for diversity." 18 Assinilationist values, however, have deep roots in American history. ${ }^{19}$ With respect to newly arrived immigrants, for example, our "most prevalent ideology" has been the concept of "Anglo-conformity," which "demanded the complete renunciation of the immigrant's ancestral culture in favor of the behavior and values of the Anglo-Saxon core group."20 Assimilationist values in this country are probably best exemplifled by the "Americanization" move-

13. For an example of the interplay between expressive and hegemonic functions of assimilationist law in the area of defamation, see Post, The Social Foundations of Defamation Law: Reputation and the Constitution, 74 CAL1F. L. REv. 691, 702-03 (1986).

14. 98 U.S. 145 (1878).

15. Id. at 164; see H.L.A. HART, LAW, L1BERTY \& MORALITY 39-43 (1963).

16. 310 U.S. $586(1940)$.

17. Id. at 597. Three years later the requirement was struck down in West Virginia State Bd. of Educ. v. Barnette, 319 U.S. 624 (1943).

18. Karenga, The Problematic Aspects of Pluralism: Ideological and Political Dimensions, in Pluralism, Racism, and Public Policy: The Search for Equality 226 (E. Clausen \& J. Bermingham eds. 1981); see Gusfield, On Legislating Morals: The Symbolic Proccss of Designating Deviance, 56 CALIF. L. REv. 54, 59 (1968). Assimilationist law can be particularly cruel when applied to immutable traits like race. In the South before World War II, for example, defamation law enforced the values of the dominant white culture, making it defamatory to say that a Caucasian was black, but not permitting blacks to sue for defamation upon being labeled white. This result followed from the fact that defamation law understood itself to be reflecting "the intrinsic difference between whites and blacks," a difference inhering in the fact that, "from a social standpoint, the negro race is in mind and morals inferior to the Caucasian." Wolfe v. Georgia Ry. \& Elec. Co., 2 Ga. App. 499, 505-06, 58 S.E. 899, $901-02$ (1907). In such extreme circumstances, where the dominant culture imposes an immutable hierarchy of caste, it is almost a misnomer to call thc law "assimilationist," since subordinate groups are given no option to join the dominant culture. Thcy are instead required to submit to that culture's impositions.

19. See, e.g., L. Friedman, Total Justice 111-20 (1987).

20. M. Gordon, Assimilation in AMERican Life: The Role of Race, Religion, and National Origins 89, 85 (1964); see W. Newman, American Pluralism: A Study of MINORITY GROUPS AND SOCIAL THEORY 53-62 (1973). 
ment that flourished during the early years of the 20th century. ${ }^{21}$

Opposed to assimilatiomst values are those of pluralism, which embrace, rather than reject, group heterogeneity. The concept of pluralism is now in rather bad repute among many legal scholars, for it has come to be associated with a vision of politics as a "struggle among selfinterested groups for scarce social resources" in which any concept of the "common good" is "incoherent, potentially totalitarian, or both."22 But pluralism has a prior and deeper meaning, one in which the affirmative value of diversity is exphicitly acknowledged and celebrated. ${ }^{23}$ In 1909, for example, William James used the term in this sense in his Hibbert Lectures, entitled $A$ Pluralistic Universe. ${ }^{24}$ Fifteen years later James' literary executor, Horace Kallen, coined the terin "cultural plurahism" to express the importance of "manyness, variety, differentiation," as opposed to what Kallen viewed as the dead umformity of Americanization. ${ }^{25}$ For Kallen, "[d]emocracy imvolves, not the elimmation of differences, but the perfection and conservation of differences. It aims, through Union, not at uniformity, but at variety . . . It involves a give and take between radically different types, and a mutual respect and mutual cooperation based on mutual understanding." 26

21. M. GORDON, supra note 20, at 98-101. For a brief overview of the "Americanization" movement, see Gleason, American Identity and Americanization, in W. PETERSEN, M. NOVAK, \& P. GleAsON, CONCEPTS OF ETHNicITY 79-96 (1982).

22. Sunstein, Interest Groups in American Public Law, 38 STAN. L. REV. 29, 32 (1985); see, e.g., W. Eskridge \& P. Frickey, Cases AND MATERIALS ON LEgISLATION 46-65 (1988); Farber \& Frickey, The Jurisprudence of Public Choice, 65 TEx. L. REV. 873, 875 (1987).

23. See Bernstein, The Varieties of Pluralism, 5 CuRRENT Issues Educ. 1, 14-16 (1985). For the history of the term "pluralism," see Breitling, The Concept of Pluralism, in THREE FACES OF Pluralism: Political, Ethnic and Religious 1-19 (S. Ehrlich \& G. Wootton eds. 1980). For illustrative examples of the variant usages of the term, see C. LARMORE, PATTERNS OF MORAL Complexity 23 (1987); D. Nicholls, Three Varieties of Pluralism (1974); Religious Pluralism (L. Rouner ed. 1984); C. Young, The Politics of Cultural Pluralism (1976); Haug, Social and Cultural Pluralism as a Concept in Social System Analysis, 73 AM. J. Soc. 294 (1967).

24. W. James, Essays in Radical Empiricism and A Pluralistic Universe (1971). James noted that "[t]he pluralistic world is thus more like a federal republic than like an empire or a kingdom." Id. at 274. Harold Laski would later cite this observation as a part of his attempt to define a "pluralist," as distinct from a "monist," theory of state sovereignty. H. LASKI, STUDIES 1N THE PROBLEM OF SOVEREIGNTY 10, 23-25 (1917).

25. H. Kallen, Culture AND Democracy 43 (1924); see Gleason, supra note 21, at 96-97.

26. Id. at 61. For further exposition of Kallen's thought, see H. KALLEN, CULTURAL PluRAlism AND the AMERICAN IDEA (1956); Ratner, Horace M. Kallen and Cultural Pluralism, in THE LEGACY OF HORACE M. KALLEN (M. Konvitz ed. 1987). Kallen's work has proved deeply influential for American educators. See, e.g., D. Gollnick \& P. ChinN, Multicultural EduCATION IN A PluRalistic Society 22-30 (1986); Castaneda, Persisting Ideological Issues of Assimilation in America: Implications for Assessment Practices in Psychology and Education, in Cultural Pluralism 60-62 (E. Epps ed. 1974); Glazer, Cultural Pluralism: The Social Aspect, in Pluralism in a Democratic Society 3-21 (M. Tumin \& W. Plotch eds. 1977); Kopan, Melting Pot: Myth or Reality?, in Cultural. Pluralism $49-54$ (E. Epps ed. 1974).

Sociologists and educators have introduced numerous variations into the concept of cultural 
The values of pluralism, like those of assimilationism, also have deep roots in American history. They reach back beyond Walt Whitman's chants in praise of the Umited States as "the modern composite nation," the "Nation of many nations," 27 to the very structure of our federalism, which seeks to the extent possible to preserve the heterogeneity inherent in local and regional differentiation. ${ }^{28}$

If assimilationist law attempts to unify society around the cultural values of a simgle dommant group, pluralist law attempts to create ground rules by which diverse and potentially competitive groups can retain their distinct identities and yet contmue to coexist. ${ }^{29}$ These ground rules can range from the requirement of state neutrality respecting conflicting rehioions, to the enforcement of norms of mutual respect, as exemplified by the group libel statute upheld in Beauharnais $v$. Illinois. ${ }^{30}$ That statute imposed criminal penalties on any expression that exposed "citizens of any race, color, creed or religion to contempt, derision, or obloquy." 1 In Beauharnais the Court stressed that the need to foster "the manifold adjustments required for free, ordered life in a metropolitan, polyglot commumity" justified the legal provision of "[s]uch group-protection on behalf of the individual."32

Pluralist law rests on two premises: that diversity is to be safe-

pluralism. Michael Novak, for example, lists five different possible meanings for the concept. Novak, Cultural Pluralism for Individuals: A Social Vision, in Pluralism in A DEMocratic SOCIETY, supra at 34-36; see W. NEWMAN, supra note 20, at 63-82. Cultural pluralism is most often contrasted with the notion of "amalgamation," id. at 63, or, as it is commonly called, the idea of the "melting pot." M. GoRDON, supra note 20 , at 115-31. The concept of amalgamation is that diverse cultural groups fuse and combine to form a new and distinctive cultural entity. From the point of view of the legal order, however, a given law would either reflect the perspective of this new entity, in which case the law would be assimilationist, or the law would vicw the new entity as simply one of a number of competing cultural groups, in which case the law would be pluralist.

27. W. Whitman, Leaves of Grass and Selected Prose 37, 518 (1950). Whitman also noted, however, that "the fear of conflicting and irreconcilable interiors, and the lack of a common skeleton, knitting all close, continually haunts me." Id. at 466 . His fear, one might say, is realized in the conception of value-free pluralism advanced by contemporary political scientists and legal academics. See supra note 22.

28. Harold Laski, for example, viewed American federalism as exemplifying pluralist values by effecting a "wide distribution of . . . sovereign powers" so as to protect a "variety of . . group life." H. LASKI, supra note 24, at 275; see Rapaczynski, From Sovereignty to Process: The Jurisprudence of Federalism after Garcia, 1985 SuP. Cr. REv. 341, 404-05. Kallen was aware of the analogy between his views and the principles of federalism, noting that "in effect the United States are in the process of becoming a federal state not merely as a union of geographical and administrative unities, but also as a cooperation of cultural diversities, as a federation or commonwealth of national culture." $\mathrm{H}$. KALLEN, supra note 25 , at 116.

29. Pluralism has been defined as aspiring toward "a plurality of cultures with their members seeking to live together in amity and mutual understanding and mutual cooperation, but maintaining separate cultures." R. Havighurst, ANThropology aNd Cultural PluRalism: Three Case Studies, Australia, New Zealand aNd USA 3 (1974).

30. 343 U.S. 250 (1952).

31. Id. at 251 (quoting Ill. Rev. STAT. ch. 38, para. 471 (1949) (repealed 1961)).

32. Id. at $259,262$. 
guarded, and that diversity inheres in the various perspectives of differing groups. "In a multi-ethnic society," the historian John Higham has written, "the assimilationist stresses a unifying ideology, whereas the pluralist guards distinctive memory." 33 The pluralist guards his distinctive memory because for him "[i]ndividuals can realize themselves, and becoine whole, only through the group that nourishes their being." 34 Hence plurahism "stresses the rights of the ethnic group over the rights of the individual."35 As Justice Black dryly noted in his dissent in Beauharnais, the Court had in effect held that the value of providing group protection was more important than that of safeguarding an "individual's choice" to speak. ${ }^{36}$

This focus on group rights, which is intrinsic to pluralist law, has always been controversial in America because it appears "to predetermine the individual's fate by his ethnic group membership."37 Americans have traditionally attached great imiportance to the image of the independent individual capable of transcending his or her particular social or ethnic background; "we strongly assert the value of our selfreliance and autonomy." 38 Thus if pluralist law protects the ability of groups to inaintain their distinctive identities, law based on the value of individualism focuses instead on the protection of individuals vis-á-vis groups. If pluralism celebrates the diversity of cultures, individualisin acclaims instead the diversity of persons.

The distinction between the two forns of law is illustrated by the case of Wisconsin v. Yoder, ${ }^{39}$ where the Supreme Court held that the free exercise clause of the first amendment prohibited the State of Wisconsin from requiring that Amish children attend public or private schools until the age of sixteen. ${ }^{40}$ In his opinion for the Court, Chief Justice Burger noted that such a requirement would pose the "very real threat of undermining the Amish community and religious practice as they exist today," and would require the Amish to "either abandon behief and be assimi-

33. Higham, Integration vs. Pluralism: Another American Dilemma, The CENTER MAGAzINE, July/Aug. 1974, at 68.

34. Id.; see also Garet, Communality and Existence: The Rights of Groups, 56 S. CAL. L. REV. 1001, 1065-75 (1983).

35. Banks, Cultural Pluralism: Implications for Curriculum Reform, in PLURALISM IN A Democratic SocieTY, supra note 26, at 228.

36. 343 U.S. at 270 (Black, J., dissenting).

37. M. GORDON, supra note 20, at 150; see also I. BERKSON, THEORIES OF AMERicanization: A Critical Study, with SPeCial Reference to THE Jewish Group 81-93 (1920).

38. R. Bellah, R. Madsen, w. Sullivan, A. Swidler, S. Tipton, Habits of the HEART: INDIVIDUALISM AND COMMTTMENT IN AMERICAN LIFE 151 (1985); see also D. RIESMAN, THE LONELY CROWD 240-60 (1961).

39. 406 U.S. 205 (1972).

40. Id. at 207. The Amish refused to permit their children to attend school after they had completed the eighth grade. Id. 
lated into society at large, or . . . to migrate to some other and more tolerant region." 41 Burger thus construed the first amendment as protecting the identity of the Amish community and as shielding that community from forced assimilation into the dominant culture.

Justice Douglas argued in dissent, however, that the Constitution safeguarded instead the rights of individual Amish children to choose whether or not to become part of the Amish community. Douglas viewed religion as "an individual experience," and hence interpreted the first amendment as guaranteeing the rights of children "to break from the Amish tradition."42

It is the future of the student, not the future of the parents, that is imperiled by today's decision. If a parent keeps his child out of school beyond the grade school, then the child will be forever barred from entry into the new and amazing world of diversity that we have today. The child may decide that that is the preferred course, or he may rebel. It is the student's judgment, not his parents', that is essential if we are to give full meaning to what we have said about the Bill of Rights and of the right of students to be masters of their own destiny. ${ }^{43}$

For Burger the "amazing world of diversity" to be protected inhered in the continuing traditions of the Amish community; for Douglas that diversity was constituted instead by the decisions of individuals to embrace or reject those traditions. Burger's opinion rests on the values of pluralism; Douglas' on the values of individualism. ${ }^{44}$

The contrast between individualism and assimilationism can appear equally stark. The latter upholds the cultural values of the dominant group; the former protects the rights of individuals to dissent from those values. In Gobitis the Supreme Court supported the values of assimilatiomism by upholding the right of a majority to require dissenters to swear allegiance to the fiag, and to the cultural perspective for which it stood. ${ }^{45}$ But three years later the Court dramatically reversed itself, and in West Virginia State Board of Education v. Barnette ${ }^{46}$ issued the classic defense of "intellectual individualism": "If there is any fixed star in our

41. Id. at 218 .

42. Id. at 243-45 (Douglas, J., dissenting).

43. Id. at 245 .

44. Of course there are many situations where the values of individualism and pluralism do not conflict. This was the case, for example, in the years immediately following Brown $v$. Board of Education, 347 U.S. 483 (1954), when the goal of desegregated education was consistent with both individualist and pluralist values. In later years, however, the question of affirmative action has separated those who view the antidiscrimination principle as grounded in the protection of individuals, from those who view it as founded in the protection of groups. Compare, e.g., Wygant v. Jackson Bd. of Educ., 106 S. Ct. 1842, 1859 n.8 (1986) (Opinion of Powell, J.) with id. at 1860 (Marshall, J., dissenting).

45. Mimersville School Dist. v. Gobitis, 310 U.S. 586 (1940). See supra text accompanying notes 16-17.

46. 319 U.S. 624 (1943). 
constitutional constellation, it is that no official, high or petty, can prescribe what shall be orthodox in politics, nationalism, religion, or other matters of opinion . . ."47 Barnette rested squarely on the individual's "right to differ as to things that touch the heart of the existing order,"48 a right that seems deeply incompatible with assimilationist law.

We are thus in a position to draw rough distinctions between three different kinds of law: assimilatiomist, pluralist, and individualist. Each postulates a different kind of relationship between cultural heterogeneity and the legal order. Assimilatiomist law strives toward social umiformity by imposing the values of a dominant cultural group; pluralist law safeguards diversity by enabling competing groups to maintain their distinct perspectives; individuahist law rejects group values altogether in favor of the autonomous choices of individuals. ${ }^{49}$

It is tempting to view these three kinds of law as sharply distinct and mutually exclusive. But they are not. There are in fact subtle and fascinating connections between them. In the next section I shall explore these connections using the example of the crime of blasphemy, which in both England and America has been one legal response to the presence of religious diversity. By examining the complex interrelationships among individualist, pluralist, and assimilationist law, I hope to offer a theoretical structure that will assist in the analysis of the feminist critique of pornography.

\section{II}

In England, blasphemy was a common law crime. It was one of the four branches of criminal libel, the other three being obscemity, sedition, and defamation. ${ }^{50}$ All four branches of libel sought to ensure that speech did not violate established norms of respect and propriety. The particular province of blasphemy was to prevent disrespect toward God, which according to Blackstone could be manifested "by denying his being or providence; or by contumelious reproaches of our Saviour Christ."

47. Id. at $641-42$.

48. Id.

49. Although these three alternatives are by no means exhaustive, see supra note 12 , they do reflect a certain internal logic with respect to law that flows from the cultural values of its surrounding society. Pluralist law rests on the twin premises that diversity is valuable and that the value of diversity inheres in group, rather than individual, perspectives. Elimmate the first premise and law will become assimilatiomist; elimmate the second and law will become imdividualist.

50. See Spencer, Criminal Libel-A Skeleton in the Cupboard (1), 1977 CRIM. L. REv. 383. English law sometimes recognizes a technical distinction between the crime of blasphemy, which is oral, and the crime of blasphemous hibel, which is written. Nothing turns on this distinction, however, and I shall ignore it in this Article.

51. 4 Blackstone, Commentaries on the laws of England 59 (1769). Benjamin Norton Defoe defined blasphemy as "vile or opprobrious Language, tending to the Dishonour of God." B. Defoe, A Compleat English Dictionary n.p. (1735). Samuel Johnson defined it as 
Although blasphemy and obscenity originally shared a common concern with regulating the profane, 52 blasphemy was in its early years most closely allied to sedition, since attacks on God and religion were viewed as equivalent to attacks on the social order. ${ }^{53}$ The classic statement in this regard was dehvered by Sir Matthew Hale in Taylor's Case, ${ }^{54}$ in which the defendant was accused of "uttering ... divers blasphemous expressions, horrible to hear, (viz) that Jesus Christ was a bastard, a whoreniaster, religion was a cheat; and that he neither feared God, the devil, or man." 55 Hale ruled

that such kind of wicked blasphemous words were not only an offence to God and religion, but a crime against the laws, State and Government, and therefore punishable.... For to say, religion is a cheat, is to dissolve all those obligations whereby the civil societies are preserved, and that Christianity is parcel of the laws of England; and therefore to reproach the Christian religion is to speak in subversion of the law. ${ }^{56}$

Underlying Taylor's Case is "the plam principle that the public importance of the Christian rehigion is so great that no one is allowed to deny its truth." 57 Proceeding on this principle, the law of blasphemy was successfully used to prosecute individuals for publishing such works as Thomas Paine's Age of Reason, ${ }^{58}$ Shelley's poem "Queen Mab,"59 and the popular Discourses of an early Deist, a minister and Fellow of Sydney Sussex College at Canibridge, which urged that the miracles reported in the New Testament be interpreted allegorically, rather than literally. ${ }^{60}$ In 1841 the English Commissioners on Crimmal Law could report "that the common law of England pumishes as an offence any general denial of

"an offering of some indignity unto God himself." S. JOHNSON, A DictionaRY OF THE ENGLiSH LANGUAGE n.p. (1756).

52. L. Levy, Treason Against God: A History of the Offense of Blasphemy 306-07 (1981). For English observers, "the line between blasphemy and obscenity was at times thin." Note, Blasphemy, 70 COLUM. L. REv. 694, 701 (1970); see also F. SchaueR, The LAW OF OBSCENITY 118 (1976); Comment, Blasphemy and Obscenity, 5 BRIT. J.L. \& Soc'Y. 89 (1978).

53. See The Law Commission, Working Paper No. 79: Offences Against Religion AND Public Worship 5-6 (1981) [hereinafter Working PAPER No. 79]; L. LEVY, supra note 52, at 303-06; G. Noxes, A History of THE CRIME OF Blasphemy 67 (1928).

54. 86 Eng. Rep. 189, 1 Vent. 293 (K.B. 1676).

55. Id.

56. Id. For discussions of Taylor's Case, see H. Bonner, Penalties Upon Opinion 28-32 (1934); L. LEVY, supra note 52, at 312-14; G. NoKES, supra note 53, at 46-61; Kenny, The Evolution of the Law of Blasphemy, 1 CAMBridge L.J. 127, 129-31 (1922); Leigh, Not To Judge But to Save: The Development of the Law of Blasphemy, 8 CAMBrian L. REV. 56, 58-63 (1977).

57. 2 J. Stephen, A History of the CRiminal LAW OF ENGLAND 475 (1883).

58. Id. at 471-73; Rex v. Williams, 26 Howell's St. Tr. 653 (K.B. 1797); Rex v. Carlile (Richard), 1 St. Tr. N.S. 1387 (1819); cf. Rex v. Carlile (Mary), 1 St. Tr. N.S. 1033 (1921).

59. Regina v. Moxon, 4 St. Tr. N.S. 693 (1841).

60. Rex v. Woolston, 94 Eng. Rep. 112, 1 Barn. K.B. 162 (1729); see H. BoNNER, supra note 56 , at $34-35$. 
the truth of Christianity, without reference to the language or temper in which such denial is conveyed." 61

Until quite recently, then, the crime of blasphemy was a paradigmatic example of assimilationist law. Christians were the dominant group in England, and blasphemy made Christian values "parcel of the laws" in England. Christian values rested on the asserted truth of certain theological and doctrinal propositions, and blasphemy prohibited those propositions from being controverted. As the Court of King's Bench was reported to have succinctly stated in Rex $v$. Woolston: "the Christian religion is established in this kingdom; and therefore [it] would not allow any books to be writ, which should tend to alter that estabhishment."62 Not only did the law of blasphemy offer no protection to subordinate or minority religions, ${ }^{63}$ but it seemed likely that even non-Anglican Christian denominations were "protected only to the extent that their fundamental beliefs [were] held in common with the established Church."64

About the middle of the 19th century, however, the crime of blasphemy began to change. One can detect the transformation in Lord Denman's charge to the jury in Regina v. Hetherington:

[U]pon the question whether it is blasphemous or not I [make] this general observation ... namely, that the question is not altogether a matter of opinion, but that it must be, in a great degree, a question as to the tone, and style, and spirit, in which such inquiries are conducted. Because, a difference of opinion may subsist, not only between different sects of Christians, but also with regard to the great doctrines of Christianity itself; and ... even discussions upon that subject may be by no means a matter of criminal prosecution, but, if they be carried on in a sober and teinperate and decent style, even those discussions may be tolerated, and may take place without criminality attaching to them; but that, if the tone and spirit is that of offence, and insult, and ridicule, which leaves the judgment really not free to act, and, therefore, eannot be truly called an appeal to the judgment, but an appeal to the wild and improper feelings of the human mind, more particularly in the younger part of the community, in that case the jury will hardly feel it possible to say that such opinions, so expressed, do not deserve the character [of blasphemy] affixed to them in this indictment. ${ }^{65}$

61. COMmissioners on CRIMINAL LAW, SIXTH REPORT 83 (1841); see also G. NOKES, supra note 53 , at 70 .

62. Woolston, 94 Eng. Rep. at 113, 1 Barn. K.B. at 163 . As recently as 1867 the House of Lords held unenforceable a contract to rent a hall for giving lectures on "The Bible shewn to be no more Inspired than any other Book," on the grounds that the contract was for the criminal purpose of propagating blasphemy. Cowan v. Milbourn, 2 L.R.- Ex. 230, 235 (1867), overruled, Bowman v. Secular Society, Ltd., [1917] App. Cas. 406.

63. Regina v. Gathercole, 116 Eng. Rep. 1140, 1157, 2 Lewim 237, 254 (1838).

64. WORKING PAPER No. 79, supra note 53, at 82. This parochialism remains true even of contemporary English blasphemy law. Id.

65. 4 St. Tr. N.S. 563, 590-91 (1841). 
For Lord Denman the crime of blasphemy did not inhere so much in the substance of what was said, as in the style in which it was said. It was not blasphemous to deny "the great doctrines of Christianity," so long as that denial were advanced "in a sober and temperate and decent style." But if Christianity were attacked in a "tone and spirit . . . of offence, and insult, and ridicule," then the attack was blasphemous. Attacks that were not civil were irrational; they did not leave "the judgment really ... free to act," and were instead appeals "to the wild and improper feelings of the human mind."

In 1883 Lord Coleridge made explicit this altered view of blasphemy. Whatever the "old cases" may have said, he explained, "the mere denial of the truth of Christianity is not enough to constitute the offence of blasphemy." 66 To be blasphemous, expression must instead be "calculated and intended to msult the feelings and the deepest religious convictions of the great majority of the persons amongst whom we live."67 The point of blasphemy was thus to prevent "outrages to the general feeling of propriety among the persons amongst whom we live," 68 and hence "if the decencies of controversy are observed, even the fundamentals of religion may be attacked witlout the writer being guilty of blasphemy." 69

Today the crime of blasphemy in England is essentially a restatement of Coleridge's view of the law. ${ }^{70}$ It is a view that has been attacked as resting on a highly vulnerable distinction between style and substance. ${ }^{71}$ The concept of assimilationist law, however, is helpful in casting Coleridge's view in a more sympathetic light, for the concept invites us to focus on the nature of the social group that Coleridge's view was designed to protect. Coleridge had in effect altered the group wliose val-

\footnotetext{
66. Regina v. Ramsay and Foote, 15 Cox C.C. 231, 236 (1883).

67. Regina v. Bradlaugh, 15 Cox C.C. 217,230 (1883).

68. Id. at 231 .

69. Ramsay and Foote, 15 Cox C.C. at 238.

70. Working PAPER No. 79, supra note 53, at 14.

71. Peter Jones, for example, has perceptively observed that "Coleridge intended his ruling in 1883 to imply" the distinction "between matter and manner." Jones, Blasphemy, Offensiveness and Law, 10 BRIT. J. PoL. Sc1. 129, $141-42$ (1980).
}

The intention behind the distinction is plain. Granted that it is possible to distinguish manner from matter, a law restricting only forms of expression need not prevent the assertion of any substantive point of view. The usual conflict between freedom of opinion and prevention of offense is therefore largely avoided....

...

The failing of the matter-manner distinction is that it supposes that statements are capable of more or less offensive formulations which are nevertheless identical in meaning. The manner of an assertion is treated as though it were so much verbal wrapping paper whose features had no bearing upon the content of the parcel. In certain cases this assumption may not be unjustified. . . . More often, however, manner and matter are so integrally related that it is impossible to distinguish the offensive manner from the offensive matter of a statement.

Id. at $142-43$. 
ues were to be implemented by blasphemy law. That group was no longer Christians holding allegiance to certain theological and doctrinal propositions; it was instead Christians holding allegiance to "the decencies of controversy." The members of this latter group, whom Coleridge explicitly understood to comprise "the great majority of the persons amongst whom we live," were not offended by the mere fact of religious difference, ${ }^{72}$ but were outraged when Christianity was not treated with the respect that they felt it deserved. They understood this respect to be coincident with the requirements of reason: blasphemy would permit attacks on Christianity if cast in the form of "an appeal to the judgment," but it would penalize sucl1 attacks if they constituted instead "an appeal to the wild and improper feelings of the human mind" that did not leave "the judgment really . . . free to act." 73

To the modern eye, it is clear that the concept of reason underlying the reformulation of blasphemy law is not universal, but rather the product of the mores of a particular culture. It is perhaps more generally true that in matters of deep human meaning, like religion (or sex), what counts as reason, as an appeal to the judgment ratlier than to "the wild and improper feelings of the human mind," is ultimately determined by the proprieties of discourse. ${ }^{74}$ That is why the purported style/substance distinction proposed by Coleridge cannot withstand close logical scrutiny: in the end the distinction rests not on logic at all, but instead on a specific cultural sense of "the decencies of controversy."

The particular group whose values these "decencies" were meant to reflect is in retrospect apparent enough. In 1930, during parliamentary debates on a proposed law to abohsh the common law crime of blas-

72. Writing in 1883, James Fitzjames Stephen could observe:

[T] he present generation is the first in which an avowed open denial of the fundamental doctrines of the Christian religion has been made by any considerable number of serious and respectable people. For many centuries the maintenance, or even the expression of opinions, suspected or supposed to involve a denial of the truth of religion in general, was regarded in the same kind of light as high treason in the temporal order of things. ... A man who did not believe in Christ or God put himself out of the pale of human society; and a inan who on important subjects thought differently from the Church, was on the high road to disbelief in Christ and in God, for belief in each depended ultimately upon belief in the testimony of the Cliurch. In our own days the physical sanctions of the law are so much more frequently appealed to, and are so much more effective than its moral sanctions, that it is only by an effort that we can understand the horror with which our ancestors regarded a man who held opinions which, in their view, were inconsistent with a real hearty assent to the principles on which they believed all human society, whether spiritual or temporal, to repose.

J. STEPHEN, supra note 57, at 438 .

73. See supra text accompanying note 65 .

74. This would not be true of instrumental reason, the success or failure of which is determined, in a more or less universal fashion, by its ability to predict and control nature. For a succinct discussion of the distinction between instrumental reason and "communicative action," see J. Habermas, TOWARd a RAtional SocietY 91-94 (J. Shapiro trans. 1970). For a fuller discussion, see-J. HABERMAS, KNOWLEDGE AND HUMAN INTERESTS (J. Sliapiro trans. 1971). 
phemy, ${ }^{75}$ it was repeatedly observed that "[w]hat it really comes to is that, where opinions are strongly held by an educated man, those opinions will be expressed in a way which the law cannot touch, while those expressed by an uneducated man, simply because he is uneducated, will come under the penalties of the law."76 After Coleridge, then, the crime of blasphemy reflected the values of educated and "respectable"77 Christians. ${ }^{78}$ Because the crime imposed these values on society as a whole, it remained deeply assimilationist in character and aspiration.

There were no successful prosecutions for blasphemy in England between the years 1922 and $1977 .{ }^{79}$ In the 1970's, however, interest arose in the potential use of blasphemy to check cultural manifestations that were viewed as objectionable. ${ }^{80}$ Ultimately this interest came to focus on a magazine entitled Gay News, which in 1976 published a poem by Professor James Kirkup entitled "The Love that Dares to Speak its Name." The poem described in exphicit detail acts of sodomy and fellatio with the body of Christ immediately after his death, and ascribed to Christ during his lifetime promiscuous homosexual practices with the Apostles and with other men. ${ }^{81}$ The poem was accompanied by a drawing of the Crucifixion featuring the body of Christ in the embrace of a Roman centurion. ${ }^{82}$ In 1977 Mrs. Mary Whitehouse, an English moral crusader, ${ }^{83}$ brought a private prosecution for blasphemy against Gay

75. The law was never passed. See Working Paper No. 79, supra note 53, at 29.

76. 234 PARL. DEB., H.C. (5th Ser.) 535 (1930) (remarks of Mr. Kingsley Griffith); see also id. at 499:

We have writers to-day who can commit the offence of blasphemy with impunity, if the offence of blasphemy is an attack on the Christian religion. There are men like Sir Arthur Keith, Mr. H. G. Wells, Mr. Bertrand Russell, Mr. Aldous Huxley and others who are able to attack the Christian religion without any danger whatever of their being prosecuted, while poor men, expressing the same point of view more bluntly and crudely, expose themselves to fine and imprisonment. That is a thoroughly unsatisfactory state of the law. After all, if one concedes the right to attack religion ... one has to concede to the people who care to do this thing the right to choose their style of doing it. Different styles are needed for different circumstances and different audiences. I do not suppose the kind of style that would go down in a select circle in the West End would be effective amongst the democracy of the East End.

(remarks of Mr. Thurtle); see also id. at 558 (remarks of Mr. Lansbury).

77. Id. at 565 (remarks of Mr. Scrymgeour).

78. The crime continued to protect the sensibilities of Christians, but not of Jcws or Moslems, or other religious minorities. Outrageous assaults on Judaism or Islam were not blasphemous. See supra note 64.

79. WORKING PAPER No. 79, supra note 53, at 17.

80. Id. at 17-18; see Jones, supra note 71, at 129.

81. Regina v. Lemon, 1979 App. Cas. 617, 632 (per Lord Diplock).

82. Id. at 660 (per Lord Scarman).

83. For a biographical study of Mary Whitehouse, who had previously been involved in antiobscenity campaigns, see M. TRACEY \& D. MORRISON, WHITEHouse (1979). Whitehouse stated that "When the [Kirkup] poem arrived on my desk, and I read it, I had one overwhelming feeling that this was the recrucifixion of Christ with 20th century weapons-with words, with obscenities, and if I sat there and did nothing I would be a traitor. It was just as simple as that." Anderson \& 
News Ltd., the publisher of Gay News, and against Denis Lenion, its editor. Lemon was convicted and sentenced to nine months imprison1nent (suspended for eighteen montlis) and fined $£$ 500, and Gay News Ltd. was fined $£ 1000 .{ }^{84}$

The case attracted widespread notice, ${ }^{85}$ and eventually wound its way up to the House of Lords. ${ }^{86}$ The actual grounds of the appeal turned on the rather technical question of whether the prosecution ought to liave demonstrated a specific intent to blasplienie on the part of the defendants. But the real underlying issue was whether the crime of blaspheniy in 1979 in England was an enibarrassnient that should be discouraged. $^{87}$ In 1979 the Law Lords, by a 3-2 vote, upheld the conviction. ${ }^{88}$ The decisive and to American eyes most compelling opinion was by Lord Scarman. What inakes his opinion particularly pertinent for this discussion, however, is its fascinating atteinpt to envision a law of blasphemy based on pluralist, ratlier than assimilationist, foundations.

Scarman was willing to assume that Leinon could establish "that he lad no intention to shock Christian believers" and had published "tlie poen not to offend Christians but to coinfort practising honiosexuals by encouraging thein to feel that there was room for them in the Cliristian religion."89 But Scarman deenied Lemon's intent to be irrelevant, because the whole point of blasphemy law was "to protect religious feeling fronı outrage and insult." Honce "[t] he cliaracter of the words pub-

Rose, Who the Hell Does She Think She Is?, 3 Poly L. REv. 13, 15 (1980) (interview with Mary Whitehouse).

84. Lemon, 1979 App. Cas. at 660. An account of the trial may be found in N. WALTER, Blasphemy in Britain: The Practice and Punishment of Blasphemy, and the Trial of GAY NEws (1977). The trial judge concluded his charge to the jury by telling the jurors

to answer the following questions about the poem: "Did it shock you when you first read

it? What was your immediate reaction? Would you be proud or ashamed to have written

it? Would you read it aloud to a Christian audience, and if you did would you blush?

What reaction would you expect from an audience of fellow Christians?"

Id. at 16. After the verdict the trial judge is reported to have "expressed his hope that, as a result of the case, the 'pendulum of public opinion would swing back towards a more healthy climate." Adam, Protecting Our Lord, New Statesman, July 15, 1977, at 74, col. 1.

85. See, e.g., Buxton, The Case of Blasphemous Libel, 1978 CRIM. L. Rev. 673.

86. Along the way the Court of Appeal upheld the fines but quashed the sentence on the grounds that "[w]e do not consider this an appropriate case for a prison sentence." 1979 Q.B. 10, 30.

87. For later assessments of this issue, see Spencer, Blasphemy: The Law Commission's Working Paper, 1981 CRIM. L. REV. 810; Blasting Blasphemy, 129 SoliC. J. 489 (1985).

88. Lemon, 1979 App. Cas. at 617. The European Commission on Human Rights later found no inconsistency between the conviction and the European Convention on Human Rights and Fundamental Freedoms. See Gay News Ltd. v. United Kingdom, 5 Eur. Comm'n H.R. 123 (1982).

89. Lemon, 1979 App. Cas. at 660.

90. Id. at 658 . Scarman rejected the notion that blasphemy was criminal because of its tendency to cause a breach of the peace. It is "a jejune exercise," he said, "to speculate whether an outraged Christian would feel provoked by the words and illustration in this case to commit a breach of peace. I hope, and happen to believe, that most, true to their Christian principles, would not allow themselves to be so provoked." Id. at 662 . 
lished matter; but not the motive of the author or publisher."11 If in Kirkup's poem "the argument for acceptance and welcome of homosexuals within the loving fold of the Christian faith [had] been advanced 'in a sober and temperate . . . style,' . . . there could have been no criminal offence committed." 92 But for Scarman "the jury (with every justification) [had] rejected this view of the poem and drawing."93

Scarman's rejection of the requirement of intent flowed from his understanding of "legal policy im the society of today"; in his view, that policy should strive to find a "way forward for a successful plural society."94 Although Scarman, as a judge, could not expand the common law crime of blasphemy to protect the religious feelings of non-Christians, he wanted to use the Lemon case as a platform to urge that the common law be changed by legislation to protect the sensibilities of all religious groups. His repudiation of the requirement of intent was integral to that ambition. He made this powerfully clear at the very outset of his opinion:

My Lords, I do not subscribe to the view that the common law offence of blasphemous hibel serves no useful purpose in the modern law. On the contrary, I think that there is a case for legislation extending it to protect the religious beliefs and feelings of non-Christians. ... In an increasingly plural society such as that of modern Britain it is necessary not only to respect the differing religious beliefs, feelings and practices of all but also to protect them from scurrility, vilification, ridicule, and contempt. ... When [in the 19th century] Lord Macaulay protested in Parliament against the way the blasphemy laws were then administered, he added (Speeches, p. 116): "If I were a judge in India, I should have no scruple about punishing a Christian who should pollute a mosque." ... When Macaulay became a legislator in India, he saw to it that the law protected the religious feelings of all. In those days India was a plural society: today the United Kingdom is also. I have perınitted myself these general observations at the outset of my opinion because, my Lords, they determine my approach to this appeal. I will not lend my voice to a view of the law relating to blasphemous libel which would render it a dead letter, or diminish its efficacy to protect religious feeling from outrage and insult. My criticism of the common law offence of blasphemy is not that it exists but that it is not sufficiently comprehensive. It is shackled by the

91. Id. at 665 (citation omitted).

92. Id. at 662 (citation omitted).

93. Id. The weakness of the style/substance distinction is starkly displayed in Lemon, for, as Jones rightly points out:

when the expression of a view occurs in a literary work-as in the Gay News case-the mode of expression is essential to the enterprise. To say that Kirkup should have produced an aeademic speculation on Christ's attitude toward homosexuality after the manner of Bishop Montefiore would be to say that he should not have written a poem.

Jones, supra note 71 , at 143.

94. Lemon, 1979 App. Cas. at 664-65. 
chains of history. ${ }^{95}$

Scarman offers a compelling vision of blasphemy law transformed by statute into an instrument of pluralism. If at common law blasphemy protected only the hegemoric status of Christianity, Scarman wants the law altered to ensure that distinct and competing religious groups treat each other with sensitivity. He beheves it imperative "[i]n an imcreasingly plural society" to use the law to enforce respect for the "religious beliefs, feelings and practices of all." Re Reformnlated in this way, the law of blasphemy would be part of a pluralist legal framework designed to maintain the integrity of diverse rehgious groups. ${ }^{97}$

Scarman's opinion represents a major and thoroughgoing effort to reestablish blaspheniy on a pluralist, rather than assimilationist basis. What is most interesting about the opinion, however, are the intrinsic limitations of that effort. For Scarman's opimion necessarily rests on the crucial (and unobtrusive) assumption that all religious groups in a "plural society" can be measured by a common metric of "outrage and insult." As we have seen in our analysis of mid-19th-century blasphemy law, however, the metric used by Scarman itself reflects particular cultural values, and there is no reason to assume that in modern England diverse religious groups would in fact share this same sense of the "decencies of controversy." Scarman's opinion therefore implicitly presupposes that religious groups should tolerate disagreement if conducted in a temperate and sober style. Despite the purity of Scarman's plurahist intentions, his effort paradoxically rests on a quintessentially assimilationist value.

This conclusion suggests that assimilationisnı and pluralisnı may

95. Id. at 658 .

96. Id. Scarman might have had in mind the Prevention of Incitement to Hatred Act which had been enacted in 1970 for Northern Ireland, and which provided:

A person shall be guilty of an offence under this Act if, with intent to stir up hatred against, or arouse fear of, any section of the public in Northern Ireland-

(a) he publishes or distributes written or other matter which is threatening, abusive or insulting; or

(b) he uses in any public place or at any public meeting words which are threatening, abusive or insulting;

being matter or words likely to stir up hatred against, or arouse fear of, any section of the public in Northern Ireland on grounds of religious belief, colour, race or ethnic or national origins.

N. Ir. Pub. Gen. Acts ch. 24, $\S 1$ (1970). The background of the statute is discussed in Leopoid, Incitement to Hatred-The History of a Controversial Criminal Offence, 1977 PUB. LAw 389, 399402. For a brief international survey of blasphemy statutes, some of which have the form suggested by Scarman, see WoRkING PAPER No. 79, supra note 53, at 40-52.

97. As Scarman well knew, blasphemy law, reinterpreted in this fashion, would be consistent with the pluralist values of the recentiy enacted provisions of The Race Reiations Act of 1976, 2 Pub. Gen. Acts 1723 , ch. $74, \S 70$, which Scarman was himself instrumental in proposing, and which essentially imposed criminal penalties for incitements to racial hatred. See I.A. MACDONALD, Race Relations-The New LAw 137 (1977). Scarman in fact explicitly drew the analogy between his vision of blasphemy and the Race Relations Act. Lemon, 1979 App. Cas. at 665. 
not be mutually exclusive concepts. Efforts to establish pluralism will always shade, at one point or another, into assimilationism. The respect for diversity, on which plurahist law is based, may well run contrary to the beliefs of some groups; pluralist attempts to create a legal framework based on the value of toleration inay well end up imposing this value on groups who do not share it. Even if diverse groups do share soine basic notions of respect and tolerance, the definitive meaning of these values will be given uniform and authoritative interpretation by legal institutions, and hence fail to reflect the various meanings that these values will have to different groups in a heterogeneous society. ${ }^{98}$ Indeed, at the most basic level, the definition and recognition of who and what will count as a group within a pluralist legal framework will necessarily rest on assimilationist values. Should Scarman's view of blasphemy become the law of England, for example, Enghish judges would face the uncoinfortable, assimilationist task of determining which practices and beliefs would count as "religions," and hence which "feelings" the crime of blasphemy ought to protect.

Pluralist law, then, inust at some level remain anchored to assimilationist law; the distinction depends, so to speak, on the length of the chain, on the degree and inanner in which the value of diversity penetrates the law. There is a soinewhat sharper line of deinarcation, however, between pluralism and individualism, as can be illustrated by contemplating what would happen in the United States to any statute that attempted to use the crime of blasphemy in the manner suggested by Lord Scarman. We can learn a great deal about the difference between pluralism and individualism by analyzing why the prospects for such a statute would be so very bleak.

One's first thought, of course, is that the religion clauses of the first amendment would flatly bar the enforcement of any blasphemy statute, pluralist or not. ${ }^{99}$ Harry Kalven, for example, has written that the "religion clauses" of the first amendinent have provided the basis for "a first great principle of consensus," which is that "In America, there is no her-

98. That is why the anthropologist Paul Bohannan defines "colonial law" as law that stems from a "unicentric power system" in societies with two or more cultures. Bohannan, The Differing Realms of Law, 67 AM. ANTHRopologist 33, 38-39 (1965). Bohannan's definition implies that pluralist law will always be hegemonic in character. But this implication may or may not be true, depending upon the extent to which a heterogenous society experiences what John Rawls has called "overlapping consensus." The presence of such a consensus may permit assimilationist ground rules for pluralist interaction to in fact serve an expressive rather than hegemonic function. See supra notes 12-13 and accompanying text; Rawls, The Idea of an Overlapping Consensus, 7 OXFORD J. LEGAL STUD. 1 (1987).

99. For an informed and sensitive discussion of this question, see Note, supra note 52 . 
esy, no blasphemy."100 The difficulty with this narrow focus on constitutional language, however, is that it ignores the framework of assumptions and values that will necessarily inform the interpretation of that language. The importance of this framework can be illustrated by an examination of the fate of blasphemy laws in the states during the period prior to the 1920's. Although blasphemy prosecutions during that period were challenged as unconstitutional because of state guarantees of rehigious freedom that were strikingly similar in form to the first amendment, ${ }^{101}$ courts uniformly interpreted these state constitutional guarantees as permitting the imposition of criminal penalties for blasphemy. ${ }^{102}$

The first and most influential case was People v. Ruggles, ${ }^{103}$ in which a defendant in New York was charged with blasphemy for having stated that "Jesus Christ was a bastard, and his nother must be a whore." 104 The New York Constitution of the time had not only "discarded rehgious establishments," 105 but had also, in order "to guard against that spiritual oppression and intolerance wherewith the bigotry and ambition of weak and wicked priests and princes have scourged mankind," guaranteed "that the free exercise and enjoyment of religious profession and worship, without discrimination or preference, shall for ever hereafter be allowed withm this State to all mankind."106 Nevertheless, the New York Supreme Court, in an opinion by Chief Justice Kent, had no difficulty in upholding the conviction:

The free, equal, and undisturbed, enjoyment of religious opinion, whatever it may be, and free and decent discussions on any religious subject, is granted and secured; but to revile, with malicious and blaspliemous contempt, the rehigion professed by almost the whole community, is an abuse of that right. Nor are we bound, by any expressions in the constitution, as some have strangely supposed, either not to punish at all, or to punish indiscriminately the like attacks upon the religion of Mahomet or of the grand Lama; and for this plain reason, that the case assumes that we are a cliristian people, and the morality of the country is

100. H. Kalven, A Worthy Tradition: Freedom of Speech in America 7 (1988) (emphasis in original).

101. During the period prior to the 1920 's, of course, the first amendment had no application to the states. By convention the first case taken to indicate a contrary conclusion is Gitlow v. New York, 268 U.S. 652 (1925).

102. See Annotation, Offense of Blasphemy, 14 A.L.R. 880, 883-85 (1921). In fact the first reported case to strike down a blasphemy statute was in 1970. See State v. West, 9 Md. App. 270, 263 A.2d 602 (1970). Theodore Schroeder, however, has reprinted an unpublished 1895 opinion issued by a lower court in Kentucky sustaining on state constitutional grounds a demurrer to an indictment for blasphemy. T. Schroeder, Constrtutional Free SpeEch Defined and DEFENDED in AN UNFiNiShed ARGUMENT IN A CASE OF BLASPHEMy 60-64 (1919).

103. 8 Johns. 290 (N.Y. 1811).

104. Id. at 291 (emphasis in original).

105. Id. at 296. N.Y. ConsT. art 38 (1777).

106. N.Y. CONST. art. 38 (1777). 
deeply ingrafted upon christianity, and not upon the doctrines or worship of those impostors. ${ }^{107}$

Kent distinguished between the formal establishment of religion through the compulsory power of the state, and the voluntary adoption by the "people of this state, im common with the people of this country, [of] the general doctrines of christianity, as the rule of their faith and practice." 108 To "scandalize" Christ was punishable not because it defied established religion, but because it was "a gross violation of decency and good order" that struck "at the root of moral obligation, and weaken[ed] the security of the social ties."109

Ruggles set a pattern that would continue for more than 110 years. ${ }^{110}$ Prosecutions for blasphemy, in their full assinilationist form, were deemed permissible, notwithstanding constitutional rights of religious freedom. It was not until quite recently that legal professionals have become convinced that prosecutions for blaspheny would violate such constitutional rights. A 1968 conviction for blaspheiny in Maryland, for example, was set aside two years later when a Maryland appellate court held that the state's 1723 blasphemy statute was "contrary to the terms of the First Amendment's prohibition of laws respecting an establishment of religion or prohibiting the free exercise thereof."111 At the time of the Maryland decision, Delaware was in the process of prosecuting for blasphemy two teenagers who had called Jesus Christ a bastard. The teenagers had been jailed and were free on bail pending trial. In light of the Maryland decision, the Delaware attorney general's office decided to drop charges. ${ }^{112}$ In 1971 in Pennsylvania, two shopkeepers were charged with blasphemy for displaying a poster reading: "Jesus Christ-Wanted for sedition, criminal anarchy, vagrancy, and conspiracy to overthrow the established government. Dressed poorly; said to be

107. Ruggles, 8 Johns. at 295 (emphasis in original).

108. Id. at $294,296$.

109. Id.

110. See, e.g., State v. Chandler, 2 Del. (2 Harr.) 553 (1837); State v. Mockus, 120 Me. 84,113 A. 39 (1921); Updegraph v. Commonwealth, 11 Serg. \& Rawle 394 (Pa. 1824). Apart from Ruggles, the most famous American blasphemy decision was Commonwealth v. Kneeland, 37 Mass. (20 Pick.) 206 (1838), in which Chief Justice Lemuel Shaw upheld a conviction for blasphemy against state constitutional challenge. The Kneeland case is discussed in BLASPHEMY 1N MASSACHUSETTS: Freedom of Conscience and The AbNer KNeeland Case (L. Levy, ed. 1973); Commanger, The Blasphemy of Abner Kneeland, 8 NEw ENG. Q. 29 (March 1935). The same blasphemy statute that was at issue in Kneeland was also used in 1928 to prosecute Horace Kallen for blasphemy. Boston Judge Recalls Warrant for Arrest on Statements in Sacco Arrest, N.Y. Times, Aug. 29, 1928, at 8, col. 1. In addressing a memorial meeting for Sacco and Vanzetti, Kallen "said that if Sacco and Vanzetti were anarchists, so was Jesus Christ, Socrates,' and several others." Id. Two years previously, the same Massachusetts blasphemy statute had been the basis for a notorious prosecution of Anthony Bimba. See Z. Chafee, The Bimba Case, in The Inquiring Mind 108 (1974); W. Wolkovich, BAy STATE “Blue” LAWs AND Bimba (1973); Note, supra note 52, at 708-09.

111. State v. West, 9 Md. App. 270, 276, 263 A.2d 602, 605 (1970).

112. The case is discussed in L. LEVY, supra note 52, at 337. 
a carpenter by trade; ill-nourished; associates with common working people, unemployed and bums. Alien; said to be a Jew." After the intervention of the American Civil Liberties Union, the county prosecutor asked that the local magistrate drop the charges. ${ }^{113}$

In each of these cases, local attempts to enforce blasphemy statutes were checked by legal professionals who beheved that the statutes were contrary to the religious freedom guaranteed by the first amendment. The literal terms of the first amendment could not have dictated this belief, for these terms are not different from those in state constitutions that had consistently been construed to allow the punishment of blasphemy. ${ }^{114}$ It is rather that the religion clauses of the first amendment are now interpreted in light of very different assumptions and values than those informing earher interpretations of equivalent language in state constitutions. It is important, therefore, to explore the values that we bring to contemporary constitutional adjudication. These values are well displayed in the important case of Cantwell v. Connecticut, ${ }^{115}$ one of the first and most influential decisions to apply the religion clauses of the first amendment to the states.

In that case Jesse Cantwell, a Jehovah's Witness, entered a Cathohic neighborhood and played for two Catholic men a phonograph record that contained an attack on all organized religious systems as "instru-

113. Id. at $337-38$.

114. Indeed in 1897 the United States Supreme Court had in dicta interpreted the first amendment in the same manner as state courts had interpreted equivalent state constitutional provisions, stating flatly that the amendment did not extend constitutional protection to "the publication of . . . blasphemous or indecent articles, or other publications injurious to public morals or private reputation." Robertson v. Baldwin, 165 U.S. 275, 281 (1897).

The Court's interpretation was at the time consistent with the opinion of authoritative commentators. Thomas Cooley, for example, had written in 1868 that:

The constitutional liberty of speech and of the press ... implies a right to freely utter and publish whatever the citizen may please, and to be protected against any responsibility for the publication, except so far as such publications, from their blasphemy, obscenity, or scandalous character, may be a public offence ....

T. CoOley, A Treatise on the Constitutional Limitations which Rest Upon the LegisLative Power of the States of The American Union 422 (1868). And Joseph Story, in interpreting the religion clauses of the first amendment, had flatly stated that:

it is impossible for those who believe in the truth of Christianity, as a divine revelation, to doubt, that it is the especial duty of government to foster and encourage it among all the citizens and subjects. This is a point wholly distinct from that of the right of private judgment in matters of religion, and of the freedom of public worship according to the dictates of one's conscience.

2 J. Story, Commentaries on the Constitution of the United States 661 (3d. ed. 1858). Story stressed that "in a republic, there would seem to be a peculiar propriety in viewing the Christian religion as the great basis, on which it must rest for its support and permanence." Id. at 662. He concluded that "[t]he real object of the [first] amendment was, not to countenance, much less to advance Mahometanism, or Judaism, or infidelity, by prostrating Christianity; but to exclude all rivalry among Christian sects, and to prevent any national ecclesiastical establishment ...." Id. at 664.

115. 310 U.S. 296 (1940). 
ments of Satan and injurious to man," and that further singled "out the Roman Catholic Church for strictures couched in terms which naturally would offend not only persons of that persuasion, but all others who respect the honestly held religious faith of their fellows."116 Cantwell was charged and convicted of the common law crime of inciting breach of the peace. ${ }^{117}$

Chief Justice Kent would certainly have viewed Cantwell's vitriolic attack on organized religion as "an abuse of" the right of free exercise of religion. Indeed in Ruggles he said that to construe the guarantee of "free exercise and enjoyment of religious profession and worship" in the New York Constitution "as breaking down the common law barriers against licentious, wanton, and impious attacks upon christianity itself, would be an enormous perversion of its meaning." 118 And Lord Scarman would certainly have deemed Cantwell's conduct to be intolerable "for a successful plural society," "119 for Cantwell had demonstrated a complete lack of respect for the religious sensibilities of others by gratuitously insulting and offending members of the Catholic religion.

It was open, therefore, to the United States Supreme Court to interpret the first amendment im light of either the assimilationist values of Kent, or the pluralist values that Scarman attempted to use thirty-nine years later to reconstruct the common law crime of blasphemy. But the Court took neither of these paths. Instead it set aside Cantwell's conviction, and offered this important gloss on what it called "the interest of the United States that the free exercise of religion be not prohibited and that freedom to communicate information and opinion be not abridged": $: 20$

In the realm of religious faith, and in that of political belief, sharp differences arise. In both fields the tenets of one man may seem the rankest error to his neighbor. To persuade others to his own point of view, the pleader, as we know, at times resorts to exaggeration, to vilification of men who have been, or are, prominent in church or state, and even to false statement. But the people of this nation have ordained in the light of history, that, in spite of the probability of excesses and abuses, these liberties are, in the long view, essential to enlightened opinion and right conduct on the part of the citizens of a democracy. The essential characteristic of these liberties is, that under their shield many types of life, character, opinion and belief can develop unmolested and unobstructed. Nowhere is this shield more necessary than in our own country

116. Id. at 309 .

117. Id. at 300 .

118. People v. Ruggles, 8 Johns. 290, 296 (N.Y. 1811).

119. See supra text accompanying notes 88-98.

120. 310 U.S. at 307. 
for a people composed of many races and of many creeds. ${ }^{121}$

According to Cantwell, then, the first amendment should be interpreted in a manner consistent with the presence of a heterogeneous society. Kent had brought to his construction of the New York Constitution the assumption that the values of Christianity provided "that moral discipline, and ... those principles of virtue, which help to bind society together."122 The Court in Cantwell, on the other hand, brought to its reading of the first amendment the assumption that society consists "of many creeds" and is divided by "sharp differences," in which "the tenets of one man may seem the rankest error to his neighbor." The presupposition of social uniformity that underhes Kent's assimilationist vision seems to have vanished from Cantwell's account, which is much closer in spirit to the "plural" society described by Scarman. But for Scarnan social diversity implied the enactment of pluralist values, so that the law could be used to protect rehigious differences from "vilification, ridicule, and contempt." For Cantwell, on the other hand, the fact of diversity led in exactly the opposite direction, toward the constitutional requirement that the law tolerate "exaggeration," "vilification," and even "excesses and abuses."

It is not difficult to perceive the lime that divides Cantwell from Ruggles; but what distinguishes Cantwell from Scarman's pluralist vision? The key lies in the fact that while Cantwell focuses its analysis on the religious speaker, Scarman concentrates instead on the offense suffered by the religious audience. There is a deeply significant asymmetry in these approaches: the speaker stands alone, whereas the outrage of the audience is generic. For Scarinan the law does not respond to the outrage of offended individuals, but to the common outrage of the members of a religious group whose group identity has been attacked. Cantwell explicitly rejects this focus on the group, choosing instead to use the law as a "shield" so that "inany types of life, character, opimon and belief can develop unmolested and unobstructed." In essence Cantwell requires that established rehigious groups, who have already developed their distinctive character and behefs, must suffer offense so that new religious groups can be born. ${ }^{123}$ Underlying Cantwell, then, hes the classic American commitment to "voluntarism,"124 to the behef that "rehigion is . . a

121. Id. at 310 .

122. Ruggles, 8 Johns. at 294.

123. In 1940, the year in which the Cantwell opinion was issued, the sect of Jehovah's Witnesses was only 68 years old, having been founded in 1872 by Charles Taze Russell in Allegheny, Pennsylvania. E. Gaustad, Historical ATLAS GF Religion in AMERICA 115-16 (1962). In the 1930's, Jehovah's Witnesses began to proselytize actively for new membership, and the sect experienced "sudden progress after 1940, all but eclipsing the development of the first sixty years." Id. at 118.

124. See P. Miller, The Life of the Mind in AMerica $40-43$ (1965). 
matter of individual choice."125

The contrast between Scarman and Cantwell might thus be formulated in this manner: For Lord Scarman religious heterogeneity presupposes a social world in which diverse religious groups already exist as part of a stable and established social fabric, whereas for Cantwell religious diversity presupposes instead a social world in which the dynamic of individual choice causes new rehgious groups continually to evolve. Thus while both Scarman and Cantwell recognize the existence of groups, Scarman assumes that the function of law is to protect the integrity of established and stable groups, whereas Cantwell assumes that the function of law is to protect the capacity of individuals to form new and different groups. The individual is the locus of value for Cantwell; the group is the locus of value for Scarman. The distinction between the two, in short, is that between individualism and pluralism. Unlike the gradient that holds together pluralism and assimilationism, the distinction between Cantwell and Scarman is quite sharp, for it turns on the more or less dichotomous determination of whether the law should be used to enforce the norms of groups as against individuals, or to protect instead the prerogatives of individuals as against groups. ${ }^{126}$

In interpreting the Constitution in light of the values and assump-

125. R. BELLAH, supra note 38 , at 225 .

126. For a discussion of the tension between pluralism and individualism, see Glazer, The Constitution and American Diversity, PUB. INT., Winter 1987, at 10-21; Gordon, Models of Pluralism: The New American Dilemma, ANNALS, March 1981, at 179-88.

The sharp break between pluralism and individualism is somewhat surprising, especially given the consensus among social scientists that individual experience is in fact largely social and intimately shaped by group identifications. The reasons for the break can perhaps be illuminated by George Herbert Mead's distinction between the "I" and the "me." Mead believed that the structure of individual identity was at root social in nature. "What makes the organized self is the organization of the attitudes which are common to the group. A person is a personality because he belongs to a community, because he takes over the institutions of that community into his own conduct." G. MEAd, ON Social Psychology 226 (A. Strauss rev. ed. 1964). But Mead also understood that there is no such thing as a completely "institutionalized individual," $i d$. at 239, because of the inherent and irreducible capacity of persons to modify or transcend those aspects of themselves that are socially given. As a consequence, Mead distinguished between the " $I$ " and the "me": "The ' $I$ ' is the response of the organism to the attitudes of the others; the 'me' is the organized set of attitudes of others which one himself assumes. The attitudes of the others constitute the organized 'me,' and then one reacts toward that as an 'I.' " Id. at 230.

The "I" is spontaneous, unpredictable, and formless; the "me" is structured and static. Mead believed that each was a fundamental and indispensable aspect of the self. He associated the "me" with "social control," and the "I" with "self-expression." Id. at 238-40. "Taken together," Mead said, "they constitute a personality as it appears in social experience. The self is essentially a social process going on with these two distinguishable phases." Id. at 233.

The sharp contrast between individualist and pluralist law can be understood as flowing from the distinction between these two phases of the self. Pluralist law upholds the values associated with the "me," which is to say with group norms and attitudes that form the structurc of personality; whereas individualist law safeguards the values associated with the "I," which is to say with the potential for individual modification and transcendence of that structure. The values of the "me" and of the "I" are necessarily complementary and interdependent, but because they are also in 
tions of individualism, Cantwell speaks for what unquestionably has become the great tradition of first amendment thought. Of course there have been dissenting voices in that tradition, but it is fair to characterize cases like Beauharnais and Yoder as ripples on the surface of a deeper and more powerful current of individualist decisions. It is worth pausing for a moment to inquire into the sociological causes of these decisions. Why in the 1930's did we begin to imterpret the first amendment to our national Constitution (as distinct from our state constitutions) in light of the principles of individualism? Was it that the natural heterogeneity of American society was more easily visible from a national, rather than a local viewpoint? Or was it instead that the federal enforcement of individualism was integral to the process of forging a distinctively national culture, a culture designed to transcend local and regional identifications? In the answers to these questions he the roots of our own constitutional perspectives, perspectives that, for example, account for our instinctive rejection of Lord Scarman's proposals for the use of blasphemy law.

If individualism is sharply demarcated from pluralism, it bears a considerably more complex relationship to assimilationism. Paradoxically, individualism and assimilationsm are discontinuous and yet interdependent. As Charles Taylor has observed, the concept of "the autonomous, self-determining individual," which lies at the heart of individualisin, presupposes a particular "social matrix" and depends for its continuing vitality on "a certain type of culture." 127

The crucial point here is this: since the free individual can only maintain his identity within a society/culture of a certain kind, he has to be concerned about the shape of this society/culture as a whole. He cannot ... be concerned purely with his individual choices and the associations formed from such choices to the neglect of the matrix in which such choices can be open or closed, rich or meager. It is important to him that certain activities and institutions flourish in society. It is even important to him what the inoral tone of the whole society is-shocking as it may be to libertarians to raise this issue-because freedoin and individual diversity can only flourish in a society where there is a general recognition of their worth. They are threatened by the spread of bigotry, but also by other conceptions of life-for exainple, those which look on originality, innovation, and diversity as luxuries which society can ill afford given the need for efficiency, productivity, or growth . . . ${ }^{128}$

Taylor's analysis suggests that at certain points the desires of autono-

tension the law must on occasion choose to cast the authority of the state behind one aspect of the self or the other.

127. 2 C. Taylor, Atomism, in Philosophy and The Human Sciences: Philosophical PAPERS 205-09 (1985).

128. Id. at 207. 
mous individuals may very well clash with the kind of general culture necessary to support autonomous individualism, and at those points individualist law will in effect be transformed into assimilationist law. ${ }^{129}$

This transformation is visible in Cantwell, which notes two different assimilatiomist justifications for the imposition of limitations on individual freedom of speech. The first justification refers to "statements likely to provoke violence and disturbance of good order."130 Cantwell states that " $[w]$ hen clear and present danger of riot, disorder, interference with traffic upon the public streets, or other immediate threat to public safety, peace, or order, appears, the power of the State to prevent or punish is obvious."131 Thus individual expression can be prevented and punished when it functions as the cause of harms or conduct that can be regulated to protect the assimilatiomist values of public safety and order. By its evocation of the "clear and present danger" test, Cantwell indicates that speech can be penalized only when there is a very strict causal connection between speech and subsequent action or harm. The strictness of the causal nexus is in part designed to maximize the amount of speech constitutionally exempt from the regulation of assimilationist values.

The second limitation on individual expression proposed by Cantwell refers to "profane, indecent, or abusive remarks directed to the person of the hearer." 132 Cantwell states that "[r]esort to epithets or personal abuse is not in any proper sense communication of information or opinion safeguarded by the Constitution, and its punishment as a criminal act would raise no question under that instrument."133 This limitation on speech is qualitatively different from the clear and present danger test, for it is grounded on the concept that speech can be regulated because it is itself intrinsically undesirable, regardless of its causal connection to subsequent harms or conduct. Cantwell expresses this limitation on speech by reference to a distinction similar to that used in mid19th-century Enghish blasphemy law. English law distinguished between "sober and temperate" expression, which was addressed to the "judg-

129. Using the perspective of George Herbert Mead, supra note 126, we might say that while it is coherent for the law in any particular case to promote the values of the "I" as against the "me," it is incoherent for the law to attempt systematically to disable the "me." This is because the "I" and the "me" are necessarily complementary; neither could exist without the other. It is thus meaningless to speak of the potcntial for individual transcendence without simultaneously speaking of the structure that is to be transcended. Since the "ine" is the internalization of the larger social organization within which the self is situated, laws that constitute and enforce that organization are in essence supportive of the "Ine." From Mead's perspective, therefore, individualist law will always transform at one point or another into either assimilationist or pluralist law. Of course, law that strives to inaximize individualist values will also strive to eliminate particular and unequal restraints on individuals, and hence take the form of assinilationism rather than pluralism.

130. Cantwell v. Connecticut, 310 U.S. 296, 309 (1940).

131. Id. at 308 .

132. Id. at 309 .

133. Id. at 309-10. 
ment," and expression imfected by a tone of "offence, and insult, and ridicule," which was addressed to "the wild and improper feelings of the human mind." 134 Cantwell offers an analogous distinction between speech that communicates "information or opinion," and speech that is "profane, indecent, or abusive."

Just as the style/substance distinction in English blasplemy law did not describe inherent properties of speech, but rather reflected cultural values relating to the "decencies of controversy," so the distinction offered by Cantwell should not be understood as describing inherent properties of language, but ratler as expressing the cultural values underlying individualism. ${ }^{135}$ For Cantwell the general culture necessary to sustain autonomous mdividualism rests on norms of interpersonal respect, and these norms in turn function as assimilationist values that limit the autonomous speech of particular individuals. "Profane, indecent, or abusive" speech violates these norms.

Cantwell's understanding of these assimilationist norms, however, has been strikingly influenced by Cantwell's underlying individualisin. The norms recognized by Cantwell differ fundamentally froin the assimilationist norms implicit in the English cases. Individuals in the English cases have the right to take offense at cominunications that insult their particular status as, say, practicing Christians. ${ }^{136}$ But the norms of respect upheld in Cantwell are quite different, for integral to that decision is the notion that the Constitution prohibits Connecticut from punishing Jesse Cantwell's speecl siniply because it is outrageous to the Catholicism of his audience. Instead the law can constitutionally intervene to censor only those statements that consist of "abusive remarks directed to the person of the hearer."137 The specific social status of an audience is immaterial to these kinds of statements, because every person has the right not to be personally abused.

Thus even when it explicitly recognizes assimilationist values that can directly regulate speech, Cantwell does so in a manner that follows the logic of individualism to its natural conclusion. Cantwell enforces a constitutional symmetry between speaker and audience: it allows the law to redress audience outrage only when that outrage stems froin cliaracteristics potentially shared by all individuals, rather than from characteristics that are constitutive of particular social or rehgious groups. ${ }^{138}$ The

134. See supra text accompanying note 65 .

135. Froin a strictly logical point of view, "profane, indecent, or abusive remarks" communicate opinion and information, just as do other kinds of statements.

136. This is also true of Scarman's pluralist reformulation of blasphemy law, which would enable individuals in all religious groups to use the law to protect thein from insults to their religious beliefs. See supra text accompanying notes 89-98.

137. 310 U.S. at 309.

138. The Supreıne Court has deınonstrated an equally determined universalism in its treatınent 
assimilationist values underlying Cantwell are thus real and palpable, but they are also extremely thin, for there is only so much that we all, as Americans, potentially share in common. The abstract and rather bloodless nature of these values, however, is the price we pay for having a first amendment grounded in individualism, rather than pluralism.

\section{III}

It is precisely the abstract nature of these values that is challenged by MacKinnon's and Dworkin's critique of pornography. The censorship of obscenity, as can now plainly be seen, is a paradigmatic expression of assimilationist law, in which the dominant culture in a community is set free to limit individual expression so as to enforce "community standards" and hence define the "tone" and "quality" of its community life. ${ }^{139}$ But the pressure of first amendment individualism has forced obscenity law to rest on the kind of thin values which are compatible with that individualism. Obscenity law thus speaks in the abstract language of "prurience," 140 a vice that is potentially universal and equally dangerous to all individuals. It does not focus at all on the particular outrage inflicted by pornography on women.

Feminists like Dworkin and MacKinnon demand that the law be transformed to take cognizance of that outrage. The problem, however, is that this outrage stems from the characteristics of a specific group (women); it is not the outrage of a generic audience composed of undifferentiated individuals. Dworkin and MacKinnon want the law to recognize that pornography demeans women, not just persons, and in this desire they are like the two Catholic men in Cantwell who would seek redress for the specific insult to their Catholicism. The feminist demand for the regulation of pornography is so controversial, in other words, because implicit within it lies the entire difference between pluralism and individualism.

There are several advantages to conceptualizing the pornography controversy in terms of the tension between pluralism and individualism. It focuses analysis on the essential grievance motivating the feminist critique; it does so in a way that minimizes the damage to basic first amendment principles; and it offers the intellectual tools to refine and sharpen

of defamation law; it has conceptualized state libel laws as redressing injuries impairing "the essential dignity and worth of every human being," Gertz v. Robert Welch, Inc., 418 U.S. 323, 341 (1974) (quoting Rosenblatt v. Baer, 393 U.S. 75, 92 (1966) (Stewart, J., concurring)), rather than injuries that would harm merely the honor of particular social groups or roles. See Post, supra note 13, at 699-719, 722-26.

139. Paris Adult Theatre I v. Slaton, 413 U.S. 49, 58 (1973); Miller v. California, 413 U.S. 15, 33 (1973). As such, of course, obscenity law has always been a thumb in the eye of the first amendment individualist tradition.

140. Miller, 413 U.S. at 30. 
the exact points in controversy, and so hopefully to expedite a resolution. The first two of these advantages can best be illustrated comparatively, through a brief discussion of three other constitutional understandings of the controversy that are prominent in the current literature.

A

A common justification offered for the suppression of pornography is that it causes discrete acts of sexual violence against individual women. This justification is not theoretically problematic, but its nature and strength depend entirely on the empirical evidence offered in its support. Given its most generous interpretation, the systematic evidence presently available does not demonstrate that pornography automatically leads to sexual violence, but rather that it causes "attitudinal" changes in men which make them more likely to countenance sexual violence against women. ${ }^{141}$ For this evidence to justify the censorship of pornography, it must be argued that the relationship between such attitudinal changes and subsequent behavior constitutes a sufficiently close causal nexus as to justify the regulation of pornography.

This is precisely the kind of argument that was traditionally offered to support the regulation of blasphemy. It was contended that blasphemy induced attitudimal changes toward religion that would lead persons to countenance anti-social acts. "Public contumely and ridicule of a prevalent religion ... threaten the public peace and order by dimimshing the power of moral precepts." ${ }^{142}$ It is also the kind of argument used by the Supreme Court in the notorious case of Debs v. United States. ${ }^{143}$ There the Court upheld the conviction of Eugene Debs for delivering an anti-war speecli to the state convention of the socialist party of Ohio, on the grounds that the "natural tendency and reasonably probable effect" of the speecli would be to induce attitudimal changes in the audience that would increase their willingness to obstruct the recruitment of American forces for World War I. ${ }^{144}$

As these examples illustrate, the government would acquire enormous and intolerable powers of censorship if it were to be given the autliority to penalize any speecli tliat would tend to induce in an audience disagreeable attitudimal changes with respect to future conduct. To avoid the potential for such censorship the Supreme Court has held that

141. C. MacK1NNon, supra note 4, at 187-89; Branit, supra note 10, at 456-57; Jacobs, supra note 10, at 10-11; Linz, Penrod, \& Donnerstein, The Attorney General's Commission on Pornography: The Gaps Between "Findings" and Facts, 1987 A.B.F. ReS. J. 713, 719-23.

142. 1 C. Tiedeman, A Treatise on State and Federal Control of Persons and Property 201 (1900); see State v. Mockus, 120 Me. 84, 94, 113 A. 39, 43 (1921); Updegraph v. Coininonwealth, 11 Serg. \& Rawle 394, 408-09 (Pa. 1822).

143. 249 U.S. 211 (1919).

144. Id. at 216. 
speech can only be penalized because of a causal nexus to future overt acts if the speech "is directed to inciting or producing imminent lawless action and is likely to incite or produce such action." 145 Pornography obviously does not meet this test. ${ }^{146}$ Given the present state of the evidence, then, the contention that pornography should be generally regulated because of its causal connection to future acts of sexual violence is profoundly at odds with the basic first amendment principle that seeks to circumscribe broad government discretion to curtail speech. ${ }^{147}$

The second justification sometimes offered for the suppression of pornography is the argument that pornography is not speech, but rather "an act of male supremacy." "148 It is contended that "[p]ornography is not expression depicting the subordination of women, but is the practice of subordination itself." 149 The power and reach of this argument can be appreciated by calling to mind J.L. Austin's concept of "performative utterances." 150 There are certain occasions when a person's speech inakes us think "that he is doing something rather than merely saying something."151 Announcing "I do" at a wedding ceremony, for example, is to perform the act of getting married. Performative utterances seem like actions because by common "convention" the acts that they perform are understood to subsist in speech. ${ }^{152}$ It may be argued that, in a similar way, certain kinds of social relationships are by convention understood to be constituted in large ineasure (although not entirely) by speech. Relationships of respect, for example, inherently involve communication, so that to speak disrespectfully is to perform an act of disrespect. From the feminist perspective, pornography is just such a disrespectful act.

This argument can be extended by noting that relationships of inferiority and superiority are also in large measure (although not entirely) constituted by speech. The status of social superiors is established and

145. Brandenburg v. Ohio, 395 U.S. 444, 447 (1969) (per curiam).

146. Emerson, supra note 10, at 135.

147. See Stone, supra note 10 , at $475-76$. This conclusion also applies to the argument that because "the nature and extent of the link between act and harm are difficult to establish," and because the harm is "potentially severe," "suggestive evidence" of a causal connection between pornography and sexual violence should be sufficient to justify legal censorship. See Sunstein, supra note 10, at 601. This argument was used by the majority of the Court in Gitlow v. New York, 268 U.S. 652 (1925), to uphold a statute suppressing anarchist speech. The Court noted that the exact causal connection between such speech and the potentially severe harm of revolution was difficult to fix. Id. at 669. It is of course possible to argue that the stringent constitutional standards that now apply to most speech should be modified and diluted for pornographic speech. The question, however, is why pornography is, in some constitutionally relevant sense, "different" from other forms of speech. The pluralist/individualist distinction seeks to offer an analytic framework within which this question can be meaningfully addressed.

148. C. MACKINNON, supra note 4, at 154; see id. at 175-76, 193-94.

149. Brest \& Vandenberg, supra note 10, at 659 (emphasis in original).

150. J. L. Austin, Philosophical Papers 233-52 (3d ed. 1979).

151. Id. at 235 (emphasis in original).

152. Id. at 237. 
confirmed by the tokens of respect that are their due; conversely, the status of social inferiors inheres in part in the disrespect with which they can be treated. Pornography can thus be seen as the practice of subordination because it is the pervasively disrespectful treatment of woinen. Even if women as a group defy the stigmatizing imputations of pornography, society's countenance of its widespread distribution indicates that this defiance is powerless before the conventional judgment of inferiority that is everywhere pornographically displayed. ${ }^{153}$

There is nothing illogical about this argunent; it rests on rather profound insights into the inanner in which social relations are constituted by speech as well as by physical actions. In its pure form, however, the argument is incompatible with any viable notion of freedoin of expression, for social relations are pervasively coinprised by speech. ${ }^{154}$ Consider the following three examples, which deal only with relationships of respect: I can, as a hiterary critic, speak disrespectfully and authoritatively about a new novel; or I can, as an outraged moralist, speak disrespectfully and witl great effect about the actions of an

153. It is in this sense, I think, that MacKinnon's recurring theme of feminine powerlessness should be understood. "Having power means, among other things, that when someone says, "This is how it is,' it is taken as being that way." C. MAcKInNon, supra note 4, at 164 . Hence, pornography "constructs women and sex," despite the dissent of women; "dissent from it becomes inaudible." Id. at 161,166 (emphasis in original).

154. The very concept of social order, for example, can be understood as constituted by speech. This is nicely illnstrated by the remarks of Francis Holt, an English writer who presented the following argument in support of an early form of the style/substance distinction in blasphemy:

[T] he law does not prohibit reasonable controversy even upon fundamental subjects, so long as it is conducted with a tone of moderation, which shews that argument is the only purpose; the writer abstaining from language and terms which are abusive and passionate, and, therein, indecorous towards the establishment, and offensive to the consciences of individuals.

What is argumentative may be very properly left to be replied to by argument; what is passionate, and therein a disturbance of the proper oconomy of the state, cannot be so safely passed over to a defence by similar weapons. - Such a sufferance would be the endurance of brawls. When the law is moved against such writers, it is not persecution: it is a defence of the public tranquillity and decency.

F. HOLT, THE LAw OF LIBEL 70-71 (1816). For Holt "public tranquillity" literally subsists in the public observance of rules of "decency"; breaches in decorum are thus equivalent to "brawls." "Passionate" speech is the same as action because Holt understands the social order to inhere in decorum, and decorum to depend upon the verbal exercise of civility and dispassionate reason. Even today the Corpus Juris Secundum defines the term "breach of the peace" to include "all violations of the public peace or order, or decorum." 11 C.J.S. Breach of the Peace $\$ 1$ (1938 \& Supp. 1987).

While we may now differ from Holt in our understanding of the particular ways in which the social order is constituted by speech, we nevertheless continue to view speech acts as integral to that order. In Chaplinsky v. New Hampshire, 315 U.S. 568 (1942), for example, the Court justified its conclusion that "fighting" words were unprotected by the first amendment on the grounds that such words "by their very utterance inflict injury." Id. at 572. Thirty years later, in Cohen v. California, 403 U.S. 15 (1971), where a defendant was convicted of disturbing the peace for writing "Fuck the Draft" on the back of his jacket, Justice Blackmun could describe "Cohen's absurd and immature antic" as "mainly conduct and little speech." Id. at 27 (Blackmun, J., dissenting). Whether or not one agrees with Blackmun's characterization, his point clearly rests upon an intelligible cultural perception. 
acquaintance; or I can, as a political partisan, speak disrespectfully and influentially about the cliaracter of the President. In eacli of these examples I have acted disrespectfully, and witl devastating consequences to the social standing of the object of my speech. We can argue about whetler or not the law should intervene to punish me in any particular case, but surely it goes too far to claim that freedom of speech is not pertinent to any of the examples because they eacli imvolve acts rather than communication.

The argument that pornography can be regulated because it is the practice of subordination, rather than speech, thus proves too much to be useful for first annendment purposes. Social relations to a great extent inhere im commumications that have the quality of performative utterances, ${ }^{155}$ and it would be entirely inconsistent with any modern understanding of the Constitution to remove such communications in wholesale fashion from the purview of the first annendment.

A third justification that has been offered to support the regulation of pornograplyy is that "pornography is more accurately treated as a physical rather than a mental experience" because it contains "neither propositional, emotive, nor artistic content."156 Pornography lacks "intellectual appeal,"157 and is "non-rational, alınost physical ... material which is purely designed to excite sexual fantasies, largely as an aid to masturbation."158 Pornography "thus contains none of the properties that are defined by the technical sense of the word 'speech,' and is thus outside the scope of the Free Speech Principle."159

This argument appears inconsistent with the contention that pornography should be regulated because it is the practice of sexual subordination. It is hard to understand how pornography can communicate attitudes of disrespect toward women if it is entirely devoid of propositional, emotive, and artistic content. If one must choose between these two characterizations of pornography, I think that it is inore accurate to conclude that pornography does convey specific attitudes toward women, and that it does so in the same inanner as any intentional act of cominunication. The notion that even a "hard-core" pornographic film could be completely empty of content strikes ine as fanciful, since at a minimum the film will be understood as attempting to coinmunicate the author's

155. Austin himself was well aware that the "contrast" between performatives and other forms of communication was not at all sharp, and that indeed "stating something is performing an act just as much as is giving an order or giving a warning." J.L. AUSTIN, supra note 150, at 246, 251. Ultimately, then, Austin came to the conclusion that "action is . . usually, at least in part, a matter of convention." Id. at 237.

156. F. Schauer, Free Speech: A Philosophical Enquiry 182-83 (1982).

157. Id. at 183 .

158. E. BARENdT, Freedom of Speech 263 (1985).

159. F. SCHAUER, supra note 156 , at 183. 
perception of what his audience will find sexually arousing. The concept of sexual arousal is of course a complex, substantive matter, filled with implications for the social understanding of gender.

To be fair to the proponents of the argument that pornography lacks all ideational content, however, it should be noted that the argument was originally developed to justify the regulation of obscenity, rather than pornography. Although the argument purports to analyze the intrinsic properties of speech, it is in fact grounded on the same assimilationist values as those that underhe the prohibition of obscenity. The argument's analysis of speech may be fallacious, but its grasp of these values is considerably more formidable.

Like Enghish blaspheiny law in the 19th century, the argument turns on the fusion of reason and civility; it rests on a distinction analogous to the opposition between speech addressed to the "judgment," and speech addressed to "the wild and improper feelings of the human mind."160 "[O]bscenity," so the argument goes in its most explicit form, "pertains, not to the realın of ideas, reason, intellectual content and truth-seeking, but to the realın of passion, desires, cravings and titillation."161 The implication of the distinction is that obscenity can be regulated because the culture of autonomous individualism depends on reason and is underinined by passion. Reformulated in this way, the argument is a serious attempt to articulate the assimilationist values that necessarily form the foundation of first amendment individualism. ${ }^{162}$ But as such the argument iguores the particular concerns raised by Dworkin's and MacKinnon's critique of pornography.

\section{B}

These three justifications for the regulation of pornography are a fair sampling of sone of the stronger arguments available in the current literature. Yet they all seem deeply unsatisfactory, either because they conflict with basic first amendment principles, or because they niss the essential point of the fentinist critique. It is as if commentators are searching for some adequate way to conceptualize the bold new claims presented by the attack on pornography. ${ }^{163}$ In fact, however, the structure of these claims should be familiar, for they are analogous to the

160. See supra text accompanying note 65.

161. Finnis, "Reason and Passion": The Constitutional Dialectic of Free Speech and Obscenity, 116 U. PA. L. REv. 222, 227 (1967); see Paris Adult Theatre I v. Slaton, 413 U.S. 49, 67 (1973).

162. For an explicit argument to this effect, see Stanmeyer, Keeping the Constitutional Republic: Civic Virtue vs. Pornographic Attack, 14 Hastings Const. L.Q. 561, 585-90 (1987). Politicians have long appreciated the power of this argument. See, e.g., Nixon, Statement about the Report of the Commission on Obscenity and Pornography, Oct. 24, 1970, in Public Papers of the Presidents OF THE UNITED STATES: RichaRd NIXON 940-41 (1971).

163. The search is sometimes quite explicit. See, e.g., Sunstein, supra note 10, at 602-08. 
question of group libel addressed in Beauharnais. ${ }^{164}$

In Beauharnais the Court held that state law could punish speech calculated to expose ethnic or religious groups to "contempt, derision, or obloquy,"165 on the grounds that "a man's job and his educational opportunities and the dignity accorded him may depend as inuch on the reputation of the racial and religious group to whicli lie willy-nilly belongs, as on his own inerits."166 The structure of tle Court's reasoning applies equally well to inembership in a gender as to membership in a religious or ethnic group. If pornograpliy subjects the group of women to conteinpt and derision by "eroticiz[nig] domniance and submission or portray[ing] woinen in a degrading manner as objects to be sexually exploited and mampulated," 167 the dignity accorded to each woman will suffer, regardless of her personal inerits.

Of course as a inatter of technical precedent Beauharnais comes to us as damaged goods. Its reasoning was crippled by New York Times $\mathrm{Co}$. v. Sullivan, ${ }^{168}$ and its lolding was unmistakably undone by Philadelphia Newspapers, Inc. v. Hepps. ${ }^{169}$ More inportantly, Beauharnais depends on tle argument that group libel is simply a variant form of individual defamation, and this argunient requires that the defendant in a group libel case be given the opportunity to establish tlie truth of his publication. ${ }^{170}$ What is at issue in the feminist critique of pornography, however, is not the falsity of the assertion that women are objects to be sexually exploited, but rather the inisult and contempt that is communicated when that assertion is inade in a particular way. Pornographically

164. Beauharnais v. Illinois, 343 U.S. 250 (1951); see Brigman, Pornography as Group Libel: The Indianapolis Sex Discrimination Ordinance, 18 IND. L. REV. 479 (1985); see also supra text accompanying notes $30-36$.

165. 343 U.S. at 251 (quoting ILL. REV. STAT. ch. 38, § 471 (1949) (repealed 1961)).

166. Id. at 263.

167. Jacobs, supra note 10, at 24.

168. 376 U.S. 254 (1964). The premise of Frankfurter's opinion in Beauharnais was that group libel was a form of defamation and hence completely outside of the purview of the first amendment. 343 U.S. at 258. Sullivan exploded this premise, holding that the regulation of "libel can claim no talismanic immunity from constitutional limitations. It must be measured by standards that satisfy the First Amendment." 376 U.S. at 269.

169. 106 S.Ct. 1558 (1986). The burden of proof was placed on the defendant in Beauharnais to establish, by way of affirmative defense, not only that "all the facts in the utterance" were true, 343 U.S. 254 n. 1, "but also that the publication [was] made "with good motives and for justifiable ends." " Id. at 265 (quoting ILL. CoNST. art. II, § 4). Hepps, on the other hand, holds that the first amendment requires that a "plaintiff bear the burden of showing falsity" when a defamation involves a matter of public concern. 106 S.Ct. at 1563 .

170. 343 U.S. at 254-56, 258. Ten years earlier David Riesman had stressed this same analogy between group libel and individual defamation. Riesman, Democracy and Defamation: Control of Group Libel, 42 Colum. L. REV. 727, $777-78$ (1942). The analogy has been criticized in Arkes, Civility and Restriction of Speech: Rediscovering the Defamation of Groups, 1974 SuP. Cr. REV. 281, 299-302. 
expressed, the assertion is a form of "personal abuse," only it is abuse targeted at a group rather than at andividual addressee.

Because the feminist cainpaign against pornography aims to suppress a specific inessage of abuse, some have rejected the purposes of the campaign as "viewpoint discrimination"171 or "thought control."172 On one level this objection is easily met. Anti-pornography legislation can effectively be drafted in formally gender-neutral terms and prohibit sexual insult to either men or women. Such a reformulation would be more consistent with the pluralist goal of maintaining respect between coinpeting groups, in this case between the groups of men and women. On a deeper level, however, this reformulation of anti-pornography legislation reinains vulnerable to the charge of viewpoint discrimination, for the legislation would still penalize messages of gender insult. It would still contain "an 'approved' view of woinen, of how they may react to sexual encounters, of how the sexes may relate to each other."173 When used in this way, however, the charge of viewpoint discrimmation apphes with equal force to Cantwell' s exclusion from first amendment protection of "profane, indecent, or abusive remarks directed to the person of the hearer." 174 Cantwell also establishes an "approved" view of how persons should relate to each other and how they should react to personal, religious, or even political disagreements.

The decisive issue, then, is not the presence vel non of viewpoint discrimination, but rather the justification for such discrimination. Reflecting its individuahist presuppositions, first amendment law has long asserted that the social costs of viewpoint discrimination are tolerable if they involve only those face-to-face messages that would be deemed universally abusive; it has characterized these messages as "of such slight social value as a step to truth that any benefit that may be derived from thein is clearly outweighed by the social interest in order and morality." 175 But first ainendment law contains no such confident assertion if the discrimination occurs against those messages that are abusive only to particular groups. As judicial reaction to the feininist anti-pornography cainpaign illustrates, ${ }^{176}$ such discrimination is much more likely to be understood as intolerable viewpoint discrinination, perhaps because of

171. Stone, supra note 10 , at 467 .

172. American Booksellers Ass'n v. Hudnut, 771 F.2d 323, 328 (7th Cir. 1985), aff'd mem., 106 S. Ct. 1172 (1986).

173. Id.

174. Cantwell v. Connecticut, 310 U.S. 296, 309 (1940). Of course if one construes the rule of Cantwell to turn on the manner of speech, rather than its content, the same point could be made about the regulation of pornography.

175. Chaplinsky y. New Hampshire, 315 U.S. 568, 572 (1942).

176. See American Booksellers, 771 F.2d 323. 
an instinctive perception that intergroup struggle is a central aspect of our political culture.

The virtue of the distinction between pluralism and individualism is that it forces us to make these different assessments explicit and to subject them to appropriate examination. There are in fact two generic grounds for apprehension conceruing the relationship between pluralism and our system of freedom of expression. The first relates to the tenuous nature of group identity in American culture; the second to the distinct kinds of assimilationist values that underlie pluralism and individualism.

Zechariah Chafee noted the first reason for unease long ago when he observed that the ultimate objection to group libel was its potential for stranglimg public discussion: "Once you start group libel laws, every influential body of men will urge that it has an equal claim to be protected by such legislation. And the wider the protection, the narrower becomes the field for unimpeded discussion of public affairs."177 Chafee's observation rests on assumptions similar to those that underlie Cantwell; he perceives group life in America as dynamic and unstable. Because groups are constantly evolving, the meaning of group identity is ambiguous, and hence there is no natural brake to claims for group protection. ${ }^{178}$ That is perhaps why the Enghish are more comfortable than we in using pluralist principles to regulate speech: categories of group identity have in England been made so inuch more definite by history and tradition.

American perceptions of group identity are exemplified by our ambivalent perception of race, which is for us the paradigmatic example of group identity made distinct through history and tradition. On the one hand we doubt whether a distinct group racial identity should really exist; we sincerely believe that race shouldn't matter and that the law should be color blind. On the other hand, when we acknowledge the existence of that identity, we do so in a way that flattens racial uniqueness into an ethnic culture that is functionally no different from the cultures of other ethnic Americans, like that of the Irish, the Italians, the Scandinavians, and so forth. When we think in terms of pluralism, in other words, even the unique category of race dissolves into a cascade of groups, each forcefully pressing its case to be recognized as the bearer of a valuable ethnic identity. Chafee is right that the first amendment

177. Z. Chafee, Government and Mass Communications 125 (1965).

178. In this regard, I cannot resist noting that the Oriental Rug Retailers of America, a professional association of rug-merchants, has recently demanded an apology from ex-White House Chief-of-Staff Donald Regan for a remark demeaning "rug-merchant type of stuff" before the congressional committee investigating the Iran-Contra arms scandal. The president of the association asserted: "Your statement was thoughtless and implies distrust of all rug merchants, and especially our membership." San Francisco Chronicle, Aug. 7, 1987, at 9, col. 4. 
would suffer harm if the law were to be used to regulate expression so as to enforce respect among all such potential groups.

But this conclusion does not settle the question of pornography. It leads instead to the question of whether there is a basis for distinguishing gender groups from all other kinds of groups, or, to put it another way, whether there is a principled manner in which the values of pluralism can be confined to pornography and not applied to expression generally. Catharine MacKinnon has written that "the situation of women is not really like anything else."179 From a constitutional point of view, much depends on the substantiation of this claim. We have been fairly successful in confining strict scrutiny under the equal protection clause to only a small number of potential groups. The question is whether we can be equally successful in the area of freedom of expression.

The second and ultimately more substantial ground for concern about the relationship between the first amendment and pluralism turns on the kind of assimilationist values that support pluralist law. As the exaniple of Cantwell illustrates, individualism tightly circumscribes the assinilationist values that can be used to characterize speech as intrinsically harmful and therefore unprotected. In the individualist realm of the first amendment, assimilatiomist values are thin and universal, for they must potentially apply to all persons. ${ }^{180}$ Such values also tend to be weak, because in order to foster a general culture of autonomous imdividualisn, it is necessary to minimize interference with the expression of autonomous individuals. At the margins the assimilationist values associated with the first amendment authorize censorship of "fighting words," or "personal abuse," or "obscenity." But in the vast majority of cases these values strain to tolerate individual differences. Thus within the realm of the first amendment we say that because "one inan's vulgarity is another's lyric,"181 "uninhibited, robust, and wide-open"182 discussion of public issues can be attained only by suspending ordinary assimilationist norins of civility and interpersonal respect. ${ }^{183}$ Pluralist law, on the other hand, presupposes assimilationist values that are richer and more aggressive. These values not only enable pluralist law to identify which groups deserve legal protection, but also to specify the norins of civility and respect that will obtain between these groups. ${ }^{184}$ In this sense pluralism conteniplates a far wider and more influential role for assimilationist law than does individualisn. For this reason the regula-

179. C. MACK1NNON, supra note 4, at 166 (emphasis in original).

180. See supra text accompanying notes 137-38.

181. Cohen v. California, 403 U.S. 15, 25 (1971).

182. New York Times Co. v. Sullivan, 376 U.S. 254, 270 (1964).

183. Post, supra note 13, at 731-39; Post, Defaming Public Officials: On Doctrine and Legal

History, (Review Essay) 1987 AM. B. Found. RES. J. 539, 553-57.

184. See supra text accompanying notes $97-98$. 
tion of pornography proposed by MacKinnon and Dworkin invites the law not only to define and enforce conceptions of group identity within the area of gender, but also to impose norms of respect and civility between genders. Individuahst law, in contrast, stresses the value of personal choice, of leaving individuals free to battle over the shape and ineaning of gender identity, so that "inany types of hife, character, opinion, and belief can develop unmolested and unobstructed."185

If the pluralist perspective of MacKinnon and Dworkin is perceived to be in tension with the first annendinent, it is because we instinctively identify that amendinent with the individualist tradition that has evolved since the 1930's. It is hard for us to imagine a system of freedom of expression that does not ultimately embody the value "of assuring individual self-fulfillment." 186 Yet it is precisely this value that MacKinnon and Dworkin call into question. To assess the constitutional inplications of their critique, we must distinguish two different meanings to the notion that the regulation of pornography is "in tension" with the first amendment. Consider, first, the kind of constitutional problem that is likely to occur in the drafting of an anti-pornography statute: The pervasiveness of gender relations and the inherent vagueness of the insult to be redressed create the troubling potential of ceding to the government broad and standardless powers of censorship. ${ }^{187}$ This potential is "in tension" with the first amendment because it is inconsistent with that distrust of government power to regulate speech which forms the very justification for the amendment. ${ }^{188}$

The arguinent that pornography should be regulated in order to assure respectful relations between the sexes, however, is not "in tension" with the first amendment in this sense. Instead the argument requires us to engage in a substantive interpretation of the purposes of the amendment, and to inquire whether we value freedom of expression because it furthers individual or group life. As the Enghish example illustrates, either approach is compatible with a system of freedom of expression. The question of which we choose turns on the kind of social world that we want to use the first ainendinent to help construct. To elect the pluralist option is not to abandon the first amendment, but rather to forsake

185. Cantwell v. Connecticut, 310 U.S. 296, 310 (1940).

186. T. EMERSon, The SySTem of FREedom of EXPRession 6 (1970).

187. On the pervasive quality of subordination in gender relationships, see E. GoFFMAN, GENDER ADVERTISEMENTS 28-51 (1979).

188. At the present time the avoidance of such discretionary powers of censorship strikes me as an essentially technical problem, to be solved by sensitive, craftsmanlike drafting. It would not be unreasonable to proceed on the assumption that by such drafting specifically first amendment concerns can be brought within the range of what we are presently willing to tolerate in the area of obscenity regulation. On the technical difficulties posed by the drafting of group libel statutes, see $Z$. CHAFEE, supra note 110, at 116-30; Tanenhaus, Group Libel, 35 CORNELL L.Q. 261, 297-302 (1950). 
the individualist assumptions underlying contemporary first amendment law.

The choice between pluralist and individualist interpretations of the first amendment is thus one of high cultural policy, and may well vary from one area of law to another. With regard to the specific matter of pornography, for example, the choice might turn on such considerations as the relationship between individual identity and gender identity, the hegemonic or expressive character of the proposed assimilationist conception of gender roles and rules of civility, ${ }^{189}$ the effectiveness and appropriateness of enforcmg normative models of gender roles through the public force of the law, and the harms caused by the absence of such enforcement. The question of freedom of expression is certainly pertinent to these inquiries, but I see no reason a priori to believe that it should be dispositive of their resolution.

The ultimate challenge posed by commentators hike MacKinnon and Dworkin, then, is not to the system of freedom of expression, but rather to our ingrained individualism. Althougl equal protection doctrine has begun to reflect pluralist values in the treatment of gender, ${ }^{190}$ our allegiance to individualism lias remained as strong as ever in the first amendment area, which concerns belief and expression rather than action. The evolving struggle over pornography will test whetler that allegiance will continue undiminished, even $\mathrm{m}$ the leermg face of pornography.

189. See supra note 98 and text accompanying notes 12-13.

190. See, e.g., Johnson v. Transportation Agency, 107 S. Ct. 1442 (1987); Williams, The Equality Crisis: Some Reflections on Culture, Courts, and Feminism, 7 WoMEN's RTs. L. REP. 175, 190-200 (1982); cf. Fiss, Groups and the Equal Protection Clause, 5 PHlL. \& PuB. AFF. 107 (1976). 
. 